\title{
HERD IMMUNITY TO SARS-CoV-2 AMONG THE POPULATION OF THE REPUBLIC OF BELARUS AMID THE COVID-19 PANDEMIC
}

\author{
A.Yu. Popova ${ }^{a}$, A.A. Tarasenko ${ }^{b}$, V.Yu. Smolenskiya ${ }^{a}$ S.A. Egorovac ${ }^{c}$ V.S. Smirnov , $^{c}$
} A.M. Dashkevich ${ }^{\mathrm{d}}$, T.N. Svetogor ${ }^{\mathrm{d}}$, I.N. Glinskaya ${ }^{\mathrm{d}}$, A.L. Skuranovich ${ }^{\mathrm{d}}$, A.M. Milichkina ${ }^{c}$, A.M. Dronina ${ }^{\mathrm{e}}$, E.O. Samoilovich ${ }^{\mathrm{e}}$, I.V. Khamitova ${ }^{\mathrm{c}}$, G.V. Semeiko ${ }^{\mathrm{e}}$, T.V. Amvrosyeva ${ }^{e}$, N.P. Shmeleva ${ }^{e}$, L.V. Rubanik ${ }^{\mathrm{e}}$, O.P. Esmanchik ${ }^{\mathrm{f}}$, I.A. Karaban ${ }^{\mathrm{b}}$, V.G. Drobyshevskayac ${ }^{c}$ G.V. Sadovnikova ${ }^{g}$, M.V. Shilovich ${ }^{\mathrm{g}}$, E.A. Podushkina ${ }^{\mathrm{g}}$, V.V. Kireichuk ${ }^{h}$, O.A. Petrova ${ }^{c}$, S.V. Bondarenko ${ }^{i}$ I.F. Salazhkova ${ }^{i}$, L.M. Tkach', L.P. Shepelevich ${ }^{\mathrm{k}}$, N.L. Avtukhova', V.M. Ivanov', A.S. Babilo', M.V. Navyshnaya', N.N. Belyaev', E.V. Zuevac, L.A. Volosar ${ }^{k}$, V.N. Verbov', I.V. Likhachev', T.O. Zagorskaya ${ }^{1}$, N.F. Morozova ${ }^{\mathrm{m}}$, Z.R. Korobova ${ }^{\mathrm{c}}$, A.V. Gubanova ${ }^{\mathrm{c}}$, Areg A. Totolian

${ }^{a}$ Federal Service for Surveillance on Consumer Rights Protection and Human Wellbeing, Moscow, Russian Federation

${ }^{b}$ Ministry of Health, Minsk, Belarus

' St. Petersburg Pasteur Institute, St. Petersburg, Russian Federation

${ }^{d}$ Republican Center for Hygiene, Epidemiology and Public Health, Minsk, Belarus

${ }^{e}$ Republican Scientific and Practical Center for Epidemiology and Microbiology, Minsk, Belarus

${ }^{f}$ Polyclinic No. 39, Minsk, Belarus

${ }^{g}$ Brest Regional Center for Hygiene, Epidemiology and Public Health, Brest, Belarus

${ }^{h}$ Vitebsk Regional Center for Hygiene, Epidemiology and Public Health, Vitebsk, Belarus

${ }^{i}$ Gomel Regional Center for Hygiene, Epidemiology and Public Health, Gomel, Belarus

${ }^{j}$ Grodno Regional Center for Hygiene, Epidemiology and Public Health, Grodno, Belarus

${ }^{k}$ Minsk City Center for Hygiene and Epidemiology, Minsk, Belarus

${ }^{\prime}$ Minsk Regional Center for Hygiene, Epidemiology and Public Health, Minsk, Belarus

${ }^{m}$ Mogilev Regional Center for Hygiene, Epidemiology and Public Health, Mogilev, Belarus

Abstract. Objective was to investigate the SARS-CoV-2 collective immunity status of the population of Belarus within the context of the COVID-19 pandemic. Materials and methods. The work was carried out according to the methodology for assessing SARS-CoV-2 population immunity, developed by Rospotrebnadzor Russia and the Ministry of Health of Belarus with the participation of the St. Petersburg Pasteur Institute, taking into account WHO recommendations.

\section{Адрес для переписки:}

Смирнов Вячеслав Сергеевич

197101, Россия, Санкт-Петербург, ул. Мира, 14,

ФБУН НИИ эпидемиологии и микробиологии им. Пастера.

Тел.: 8 (911) 948-59-22 (моб.).

E-mail:vssmi@mail.ru

\section{Для цитирования:}

Попова А.Ю., Тарасенко А.А., Смоленский В.Ю., Егорова С.А., Смирнов В.С., Дашкевич А.М., Светогор Т.Н., Глинская И.Н.,

Скуранович А.Л., Миличкина А.М., Дронина А.М., Самойлович Э.О.,

Хамитова И.В., Семейко Г.В., Амвросьева Т.В., Шмелева Н.П., Рубаник Л.В.,

Есманчик О.П., Карабан И.А., Дробышевская В.Г., Садовникова Г.В.,

Шилович М.В., Подушкина Е.А., Кирейчук В.В., Петрова О.А.,

Бондаренко С.В., Салажкова И.Ф., Ткач Л.М., Шепелевич Л.П.,

Автухова Н.Л., Иванов В.М., Бабило А.С., Навышная М.В., Беляев Н.Н.,

Зуева Е.В., Волосарь Л.А., Вербов В.Н., Лихачев И.В., Загорская Т.О.,

Морозова Н.Ф., Коробова З.Р., Губанова А.В., Тотолян Арег А.

Коллективный иммунитет к SARS-CoV-2 населения Республики Беларусь

в условиях пандемии COVID-19 // Инфекция и иммунитет. 2021. T. 11, № 5.

С. 887-904. doi: $10.15789 / 2220-7619-H$ IT-1798

\section{Contacts:}

Vyacheslav S. Smirnov

197101, Russian Federation, St. Petersburg, Mira str., 14,

St. Petersburg Pasteur Institute.

Phone: +7 (911) 948-59-22 (mobile).

E-mail:vssmi@mail.ru

\section{Citation:}

Popova A.Yu., Tarasenko A.A., Smolenskiy V.Yu., Egorova S.A., Smirnov V.S., Dashkevich A.M., Svetogor T.N., Glinskaya I.N., Skuranovich A.L., Milichkina A.M., Dronina A.M., Samoilovich E.O., Khamitova I.V., Semeiko G.V., Amvrosyeva T.V., Shmeleva N.P., Rubanik L.V., Esmanchik O.P., Karaban I.A., Drobyshevskaya V.G., Sadovnikova G.V., Shilovich M.V., Podushkina E.A., Kireichuk V.V., Petrova O.A., Bondarenko S.V., Salazhkova I.F., Tkach L.M., Shepelevich L.P., Avtukhova N.L., Ivanov V.M., Babilo A.S., Navyshnaya M.V., Belyaev N.N., Zueva E.V., Volosar L.A., Verbov V.N., Likhachev I.V., Zagorskaya T.O., Morozova N.F., Korobova Z.R., Gubanova A.V., Totolian Areg A. Herd immunity to SARS-CoV-2 among the population of the Republic of Belarus amid the COVID-19 pandemic // Russian Journal of Infection and Immunity = Infektsiya i immunitet, 2021, vol. 11, no. 5, pp. 887-904. doi: 10.15789/2220-7619-HIT-1798 
The Bioethics Committee of Belarus and the local ethics committee of the St. Petersburg Pasteur Institute approved the study. Selection of participants was carried out using a questionnaire method and online technology (internet, cloud server). Volunteers were randomized into seven age groups (years of age): 1-17; 18-29; 30-39; 40-49; 50-59; 60-69; and $70+$. Regional randomization ensured proportional representation of volunteers from each region, and no more than 30 people were included from one enterprise. In accordance with manufacturer instructions, blood plasma samples were analyzed for: $\mathrm{IgG}$ antibodies (Abs) to the SARS-CoV-2 nucleocapsid (Nc) using a quantitative ELISA test system; and IgG Abs to the receptor binding domain (RBD) of the SARS-CoV-2 S (spike) surface glycoprotein using a qualitative ELISA test system. Statistical processing was carried out using Excel 2010 and other software. Statistical differences were designated as significant when $\mathrm{p}<0.05$, unless otherwise indicated. Results. The level of seroprevalence, in terms of Abs to Nc among the Belarusian population, was 38.4\% (95\% CI 37.6-45.4). The highest Ab levels were found among individuals in older age groups (50-70+ years old). The lowest were found in children 1-17 years old and in young people 18-39 years old The distribution of seroprevalence across Belarusian regions was relatively homogeneous, with the exception of the Minsk Region, where a statistically significant decrease in the indicator was noted. In terms of profession, the largest share of seropositive individuals was found among transportation workers; the smallest was found in business. The moderate COVID-19 incidence has not led to a dramatic increase in the number of contacts. The base reproduction number (R0) was 1.3. In the Republic of Belarus, there was a moderate level of asymptomatic COVID-19 among seropositive individuals (45.3\% [95\% CI 44.0-46.7]). This form of infection was observed most often among children aged 1-17 years old (65.0\% [95\% CI 61.3-68.6]). In parallel with seroprevalence assessment, SARS-CoV-2 vaccination was carried out. We used two vaccines: Gam-COVID-Vac (also known as Sputnik V, developed by Gamaleya National Center for Epidemiology and Microbiology, Russia); and BBIBP-CorV (Sinopharm, PRC). Vaccination against SARS-CoV-2 was accompanied by an increase in the level of anti-RBD Abs (95\% [95\% CI 94.7-96.7]). Taking into account the vaccination of a subset of the population with BBIBP-CorV, the overall herd immunity, inferred from the analyzed indicators (presence of anti-Nc or anti-RBD Abs), was 47.1\% (95\% CI 46.3-48.0). Conclusion. COVID-19 in Belarus was characterized by a moderately pronounced course of the epidemic process. The threshold level of herd immunity to SARS-CoV-2 has not yet been reached, as a result of which the conditions for progression of the epidemic remain.

Key words: coronaviruses, SARS-CoV-2, COVID-19, morbidity, seroprevalence, asymptomatic course, Republic of Belarus, population, vaccination, anti-nucleocapsid antibodies, anti-RBD antibodies, Gam-COVID-Vac vaccine (Sputnik V), BBIBP-CorV vaccine.

\section{КОЛЛЕКТИВНЫЙ ИММУНИТЕТ К SARS-CoV-2 НАСЕЛЕНИЯ РЕСПУБЛИКИ БЕЛАРУСЬ В УСЛОВИЯХ ПАНДЕМИИ COVID-19}

Попова А.Ю. ${ }^{1}$, Тарасенко А.А. ${ }^{2}$, Смоленский В.Ю. ${ }^{1}$, Егорова С.А. ${ }^{3}$, Смирнов В.С. ${ }^{3}$, Дашкевич А.М. ${ }^{4}$, Светогор Т.Н. ${ }^{4}$, Глинская И.Н. ${ }^{4}$, Скуранович А.Л. ${ }^{4}$, Миличкина А.М. ${ }^{3}$, Дронина А.М. ${ }^{5}$, Самойлович $Э .0 .5$, Хамитова И.В. ${ }^{3}$, Семейко Г.В. ${ }^{5}$, Амвросьева Т.В. ${ }^{5}$, Шмелева Н.П. ${ }^{5}$, Рубаник Л.В. ${ }^{5}$, Есманчик О.П. ${ }^{6}$, Карабан И.А. ${ }^{2}$, Дробышевская В.Г. ${ }^{3}$, Садовникова Г.В. ${ }^{7}$, Шилович М.В. ${ }^{7}$, Подушкина Е.А. ${ }^{7}$, Кирейчук В.В. ${ }^{8}$, Петрова О.А. ${ }^{3}$, Бондаренко С.В. ${ }^{9}$, Салажкова И.Ф.9, Ткач Л.М. ${ }^{10}$, Шепелевич Л.П.11, Автухова Н.Л.12, Иванов В.М. ${ }^{3}$, Бабило А.С. ${ }^{12}$, Навышная М.В. ${ }^{12}$, Беляев Н.Н. ${ }^{3}$, Зуева Е.В. ${ }^{3}$, Волосарь Л.А. ${ }^{11}$, Вербов В.Н. ${ }^{3}$, Лихачев И.В. ${ }^{3}$, Загорская Т.О. ${ }^{12}$, Н.Ф. Морозова ${ }^{13}$, Коробова 3.Р. ${ }^{3}$, Губанова А.В. ${ }^{3}$, Тотолян Арег А. ${ }^{3}$

${ }^{I}$ Федеральная служба по надзору в сфере защиты прав потребителей и благополучия человека, Москва, Россия

${ }^{2}$ Министерство здравоохранения, г. Минск, Беларусь

${ }^{3}$ ФБУН НИИ эпидемиологии и микробиологии имени Пастера, Санкт-Петербург, Россия

${ }^{4}$ ГУ Республиканский центр гигиены, эпидемиологии и общественного здоровья, г. Минск, Беларусь

${ }_{5}^{5}$ Республиканский научно-практический центр эпидемиологии и микробиологии, г. Минск, Беларусь

${ }^{6}$ Городская поликлиника № 39, г. Минск, Беларусь

${ }^{7}$ ГУ Брестский областной центр гигиены, эпидемиологии и общественного здоровья, г. Брест, Беларусь

${ }^{8}$ ГУ Витебский областной центр гигиены, эпидемиологии и общественного здоровья, г. Витебск, Беларусь

${ }^{9}$ ГУ Гомельский областной центр гигиены, эпидемиологии и общественного здоровья, г. Гомель, Беларусь

${ }^{10}$ ГУ Гродненский областной центр гигиены, эпидемиологии и общественного здоровья, г. Гродно, Беларусь

${ }^{11}$ ГУ Минский городской центр гигиены и эпидемиологии, г. Минск, Беларусь

${ }^{12}$ ГУ Минский областной центр гигиены, эпидемиологии и общественного здоровья, г. Минск, Беларусь

${ }_{13}^{13}$ УЗ Могилевский областной иентр гигиены, эпидемиологии и общественного здоровья, г. Могилев, Беларусь

Резюме. Задача - изучить коллективный иммунный статус населения Беларуси против SARS-CoV-2 в контексте пандемии COVID-19. Материалы и методы. Работа проводилась по методике оценки иммунитета населения SARS-CoV-2, разработанной Роспотребнадзором России и Минздравом Беларуси при участии Санкт-Петербургского института Пастера с учетом рекомендаций ВОЗ. Комитет по биоэтике Беларуси и локальный этический комитет Санкт-Петербургского института Пастера одобрили исследование. Отбор участников проводился анкетным методом и онлайн-технологиями (Интернет, облачный сервер). 
Добровольцы были рандомизированы на семь возрастных групп (лет): 1-17 лет, 18-29, 30-39, 40-49, 50-59, 60-69 и 70+. Региональная рандомизация обеспечила пропорциональное представительство волонтеров от каждого региона, и от одного предприятия было включено не более 30 человек. В соответствии с инструкциями производителя образцы плазмы крови были проанализированы на IgG-антитела (Abs) к нуклеокапсиду SARS-CoV-2 (Nc) с использованием количественной тест-системы ELISA и на IgGантитела к рецептор-связывающему домену (RBD) поверхностного гликопротеина SARS-CoV-2 S (шип) с использованием качественной тест-системы ELISA. Статистическая обработка проводилась в программе Excel 2010 и в ряде других. Статистические различия считались значимыми при $\mathrm{p}<0,05$, если не указано иное. Результаты. Уровень распространенности серотипов по отношению Abs к Nc среди населения Беларуси составил 38,4\% (95\% ДИ 37,6-45,4), самые высокие уровни Аb были зарегистрированы среди лиц в старших возрастных группах (50-70+ лет), самые низкие - у детей 1-17 лет и у молодежи 18-39 лет. Распределение серопревалентности по регионам Беларуси было относительно однородным, за исключением Минской области, где было отмечено статистически значимое снижение показателя. В профессиональном отношении наибольшая доля серопозитивных лиц была обнаружена среди транспортных работников, наименьшая в сфере предпринимательства. Умеренная заболеваемость COVID-19 не привела к резкому увеличению числа контактов. Базовый номер репродукции (R0) равнялся 1,3. В Республике Беларусь среди серопозитивных лиц отмечен средний уровень бессимптомного COVID-19 (45,3\% [95\% ДИ 44,0-46,7]). Эта форма заражения чаще всего наблюдалась у детей в возрасте от 1 до 17 лет (65,0\% [95\% ДИ 61,3-68,6]). Параллельно с оценкой серологической распространенности проводилась вакцинация против SARS-CoV-2. Мы использовали две вакцины: Gam-COVID-Vac (также известный как «Спутник V», разработанный Национальным исследовательским центром эпидемиологии и микробиологии им. Н.Ф. Гамалеи, Россия) и BBIBP-CorV (Sinopharm, KHP). Вакцинация против SARS-CoV-2 сопровождалась повышением уровня антител к RBD (95\% [95\% ДИ 94,7-96,7]). Принимая во внимание вакцинацию подгруппы населения BBIBP-CorV, общий коллективный иммунитет, выведенный из анализируемых показателей (наличие антител против Nc или против RBD), составил 47,1\% (95\% ДИ 46,3-48,0). Заключение. COVID-19 в Беларуси характеризовался умеренно выраженным течением эпидемического процесса. Пороговый уровень коллективного иммунитета к SARS-CoV-2 еще не достигнут, вследствие чего сохраняются условия для развития эпидемии.

Ключевые слова: коронавирусы, SARS-CoV-2, COVID-19, заболеваемость, серологическая распространенность, бессимптомное течение, Республика Беларусь, численность населения, вакцинация, антинуклеокапсидные антитела, антитела против RBD, вакцина Gam-COVID-Vac (Sputnik V), вакцина BBIBP-CorV.

\section{Introduction}

The Republic of Belarus is a country located practically at the center of Europe. In fact, the Republic's territory includes Europe's geographical center $\left(55^{\circ} 30^{\prime} \mathrm{N}, 28^{\circ} 48^{\prime} \mathrm{E}\right)$. It is quite natural that the novel coronavirus infection (COVID-19), which began in the Chinese city of Wuhan and almost instantly spread throughout the world, could not bypass an entire Eastern European country like Belarus. The first COVID-19 case was detected on February 28, 2020 in a student who arrived from Iran [1]. In the following month, predominantly sporadic cases were recorded. Only on March 30, 2020, were 58 infections detected in a single day for the first time [3].

Two days later, the first wave of the disease started. The peak incidence, of 969 primarily infected people per day, fell on May 17, 2020 (Fig. 1). Following that, there was a gradual decrease in the number of infected people, reaching a plateau from August 5 to 21, when the number of new cases did not exceed 100127 people per day. Starting from August 21, 2020, an uptrend formed. Incidence grew rapidly and reached a maximum (1,972 people/day) on January 13, 2021. This figure was 2-fold higher than the maximum of the first rise. A subsequent, uneven decrease was observed in the period until July 15, 2021 (the ob- servation period). However, at the end of this period, the number of new cases per day on different days ranged from 600 to 1,300 people. In aggregate, as of July 22, 2021: the incidence rate in the Republic was $4.7 \% 000$; and the number of deaths was $0.8 \%$ of the total number of infected [3].

Arrows mark the sampling period for determining the level of Ab to SARS-CoV-2 Nc (14.05.202119.05. 2021, the $19^{\text {th }}-20^{\text {th }}$ week of the year). The black solid line shows the trend curve described by the $6^{\text {th }}$ degree polynomial equation. The regression equation and coefficient of determination $\left(\mathrm{R}^{2}\right)$ are shown on the graph.

A feature of Belarus is the tactics aimed at minimizing restrictive government measures [20, 39]. In the country, a 14-day self-isolation was introduced for persons arriving from abroad or having contact with COVID-19 patients. In addition, the use of protective masks and observance of social distancing in public places (public transport, trade establishments, etc.) were strongly recommended. Distance learning and schedule changes in schools and universities were also used [39, 51]. No other restrictive government measures were applied in the Republic. As the official statistics show, the refusal to introduce global restrictions did not cause a significant increase in the number of cases, the number of which remains 


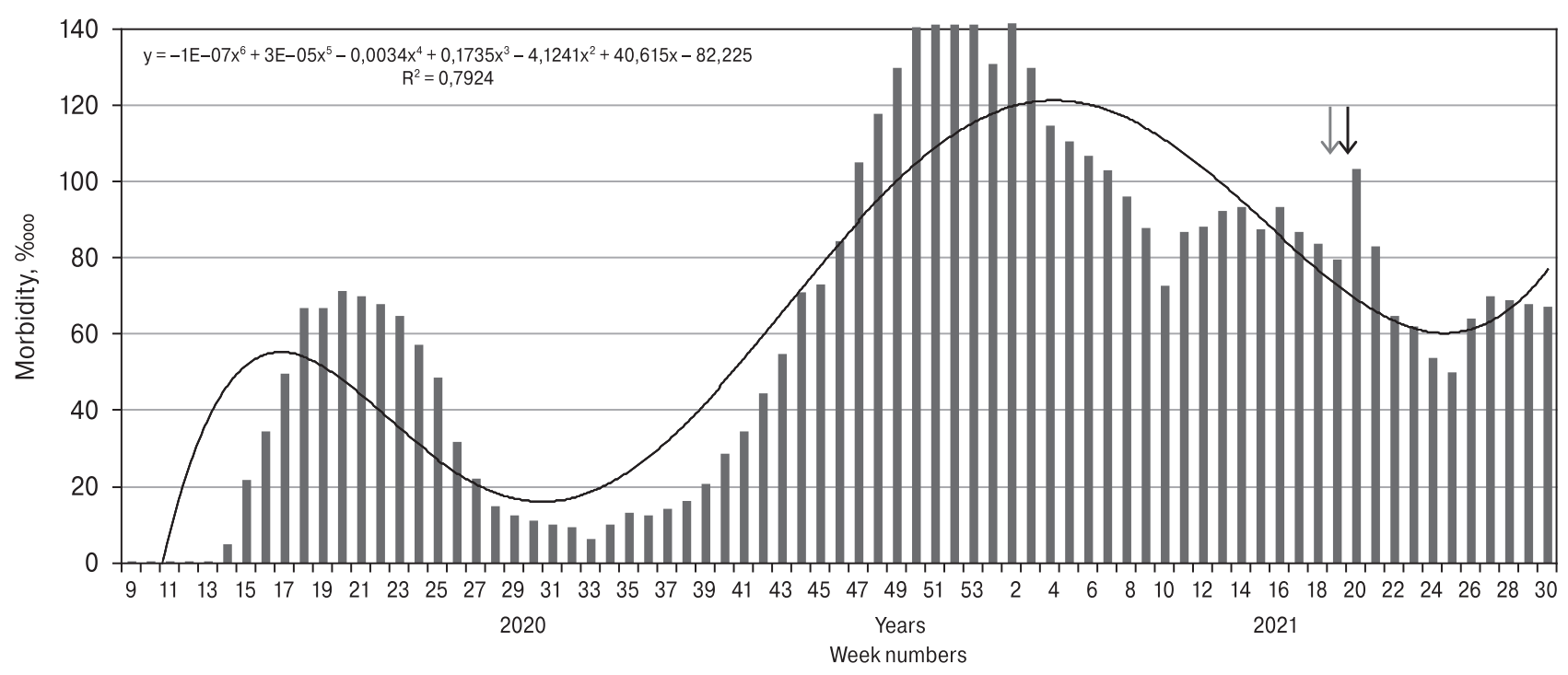

Figure 1. COVID-19 morbidity dynamics of the Belarusian population during the pandemic, 2020-2021

at about $50.00 \%$ ooo. In the global ranking of countries, Belarus ranks $51^{\text {st }}$ in terms of morbidity.

A likely reason for the relatively low COVID-19 incidence may be low population density (45.5 per $\mathrm{km}^{2}$ ). In neighboring countries, this level was lower only in Latvia and the Smolensk Region of Russia (29.0 and 18.5 per $\mathrm{km}^{2}$, respectively). Ukraine (75.8 per $\left.\mathrm{km}^{2}\right)$, Poland $\left(121.1\right.$ per $\left.\mathrm{km}^{2}\right)$, and the Czech Republic (135.7 per $\mathrm{km}^{2}$ ) feature much higher population densities [5]; their incidence values were from 1.1 to 3.3-fold higher than that of Belarus. It is logical to assume that, in the context of relatively low morbidity, seroprevalence may also be low. A significant decrease in the intensity of contacts with residents of foreign countries, as well as the initiation of vaccination against SARS-CoV-2, may have positively affected the epidemic situation. Unfortunately, we could not find any published data specifically on this issue.

The objective of the study was to investigate the (SARS-CoV-2) population immunity structure in Belarus at the $15^{\text {th }}$ month of the COVID-19 pandemic.

\section{Materials and methods}

\section{Formation and randomization of the cohort of volunteers}

The study was organized and carried out within a framework for scientific cooperation between countries of Eastern Europe, Transcaucasia, and Central Asia. The framework is in accordance with a Russian Government Order (dated 06.18.2021, No. 1658-p.) and decisions by: the head of the Russian Federal Service for Supervision of Consumer Rights Protection and Human Welfare (Rospotrebnadzor); and the Deputy Minister of Health, Chief State Sanitary Doctor, of Belarus. A cross-sectional cohort randomized study of SARS-CoV-2 herd immunity was carried out according to a program developed by Rospotrebnadzor with the participation of the St. Petersburg Pasteur Institute, taking into account WHO recommendations [52]. The study was conducted on May 14-19, 2021 (weeks 19-20 of the year). In all stages of the study (organizing, collecting, and analyzing results), cloud (Internet) technologies were used [15].

Table 1. Distribution of volunteers by region

\begin{tabular}{|l|c|c|c|}
\hline \multicolumn{1}{|c|}{ Region } & Population & Number of individuals studied & Representation \% (95\% Cl) \\
\hline Brest Region & $1,347,000$ & 1,690 & $0.13(0.12-0.13)$ \\
\hline Vitebsk Region & $1,133,000$ & 1,648 & $0.15(0.14-0.15)$ \\
\hline Grodno Region & $1,025,000$ & 1,685 & $0.16(0.15-0.17)$ \\
\hline Gomel Region & $1,386,000$ & 1,606 & $0.12(0.11-0.12)$ \\
\hline Mogilev Region & $1,023,000$ & 1,718 & $0.17(0.16-0.18)$ \\
\hline Minsk Region & 147,2000 & 1,602 & $0.11(0.10-0.11)$ \\
\hline Minsk & $2,020,000$ & 2,977 & $0.14(0.14-0.15)$ \\
\hline Total & $\mathbf{9 , 4 0 8 , 4 4 0}$ & $\mathbf{1 2 , 9 2 6}$ & $\mathbf{0 . 1 4}(\mathbf{0 . 1 4}-\mathbf{0 . 1 4 )}$ \\
\hline
\end{tabular}


In accordance with the chosen methodology, the first step was the formation and subsequent randomization of a volunteer cohort by means of questionnaires. Each volunteer, or their legal representative, was familiarized with the goals and conditions of the upcoming study and signed an informed consent. The study was organized in accordance with the provisions of the Declaration of Helsinki and approved by the Bioethics Committee of Belarus (protocol No. 2, dated 13.05.2021) and the local ethics committee of the St. Petersburg Pasteur Institute (protocol No. 64, dated 26.05.2020). In accordance with the specific equation of the De Moivre-Laplace Theorem [16], 12,926 people, from all regions of Belarus, were selected to participate in the study. Volunteers were randomized according to their place of residence, taking into account proportional representation from each region of the Republic (Table 1).

In total, $0.14 \%$ (95\% CI $0.13-0.14)$ of the total population was selected for the cohort of volunteers throughout Belarus. In regions of the Republic, the representation varied from 0.11 to $0.17 \%$. Although the differences in SARS-CoV-2 seroprevalence between regions turned out to be statistically significant, it is unlikely that the range of mean values $(0.06 \%)$ in the subpopulations could have a significant impact on the state of seroprevalence in the Republic with a population of 9,349 million people. The cohort of volunteers consisted of 4,375 men and 8,551 women (a ratio of approximately 1:2). In addition to regional randomization, the cohort was stratified into seven age groups (Table 2).

\section{Vaccination against SARS-CoV-2}

Some of the volunteers took part in coronavirus vaccination launched in Belarus. The program used two vaccines. The first, Gam-COVIDVac (Sputnik V), was developed by the Gamaleya National Center for Epidemiology and Microbiology (Moscow, Russia) [35, 56]. It is a vector, heterologous 2-component vaccine containing: recombinant adenovirus type 26 (rAd26); and a vector of recombinant adenovirus type 5 (rAd5). Both components carry the SARS-CoV-2 spike glycoprotein gene (rAd26-S, rAd5-S). The second vaccine was an inactivated design, BBIBP-CorV, manufactured by Sinopharm Group Co., Ltd., (Shanghai, PRC) [50, 54]. Vaccinations were carried out in accordance with their instructions for use. As a consequence of their compositions, immunity resulting from vaccination with Sputnik V is mainly aimed at binding the RBD of the spike protein [32], while the BBIBPCorV vaccine (inactivated) induces Abs against all viral antigens [37].

\section{Analysis of volunteers for the presence of SARS- CoV-2 antibodies}

All volunteers in the formed cohort underwent blood sampling from the cubital vein $(3 \mathrm{ml}$ into va-
Table 2. Age structure of the surveyed volunteer cohort

\begin{tabular}{|c|c|c|c|}
\hline \multirow{2}{*}{\multicolumn{2}{|c|}{$\begin{array}{l}\text { Age group, } \\
\text { in years }\end{array}$}} & \multicolumn{2}{|c|}{ Surveyed } \\
\hline & & $\begin{array}{c}\text { absolute } \\
\text { number }\end{array}$ & $\begin{array}{l}\% \text { of total } \\
\text { surveyed }\end{array}$ \\
\hline \multicolumn{2}{|l|}{$1-17$} & 1,727 & 13.4 \\
\hline \multirow{3}{*}{ Including } & $1-6$ & 199 & $11.5^{\star}$ \\
\hline & $7-13$ & 803 & $46.5^{\star}$ \\
\hline & $14-17$ & 725 & $42.0^{*}$ \\
\hline \multicolumn{2}{|l|}{$18-29$} & 1,761 & 13.6 \\
\hline \multicolumn{2}{|l|}{ 30-39 } & 1,862 & 14.4 \\
\hline \multicolumn{2}{|l|}{$40-49$} & 1,900 & 14.7 \\
\hline \multicolumn{2}{|l|}{ 50-59 } & 1,958 & 15.2 \\
\hline \multicolumn{2}{|l|}{ 60-69 } & 1,911 & 14.8 \\
\hline \multicolumn{2}{|l|}{$70+$} & 1,807 & 13.9 \\
\hline \multicolumn{2}{|l|}{ Total } & 12,926 & 100.0 \\
\hline
\end{tabular}

Note. Since children feature different stages of general immune development $1-17$ years old children group was divided into three subgroups to refine analysis: 1-6; 7-13; and 14-17 years old * - pediatric subgroup values are percentage of the overall group (1-17 years old).

cutainers containing EDTA). Blood plasma samples, after separation from the cellular component, were used for the quantitative determination of $\mathrm{IgG}$ Abs to the Nc (SARS-CoV-2) antigen by enzyme immunoassay, using a reagent kit manufactured by the St. Petersburg Pasteur Institute. In addition, vaccinated volunteers were qualitatively analyzed for the presence of anti-RBD Abs using a reagent kit developed by the Gamaleya National Center for Epidemiology and Microbiology.

\section{Statistical analysis}

Data processing was performed using Excel 2010. Confidence intervals (95\% CI) were calculated by the method of A. Wald and J. Wolfowitz [49], with correction by the method of A. Wald and J. Wolfowitz [49], with correction by A. Agresti and B.A. Coull [18]. Correlation analysis was performed according to Spearman's method. The statistical significance of differences was calculated by the z-test, using an online calculator [2].

\section{Results}

\section{Age distribution of Nc antigen seroprevalence in the Belarusian population}

The share of residents with Abs to SARS-CoV-2 Nc (seroprevalence), in Belarus as a whole at 15 months after epidemic onset, was $38.4 \%$ (95\% CI 37.6-39.3) (Table 3). Seroprevalence among men (39.7\% [95\% CI 38.3-41.2]) was higher than that among women (37.8\% [95\% CI 36.8-38.8]). Statistical differences are significant at $\mathrm{p}<0.05$.

The largest shares of seropositive persons were noted among volunteers in 3 older groups: 50-59; 
Table 3. Seroprevalence of anti-Nc antibodies in different volunteer age groups

\begin{tabular}{|l|l|c|c|c|}
\hline \multicolumn{2}{|c|}{ Age group, years } & Total studied (N) & Seropositive (n) & Seroprevalence, \% (95\% CI) \\
\hline $\mathbf{1}$ & $1, \mathbf{1 7}$ & 199 & 677 & $39.2(33.3-41.6)$ \\
\hline \multirow{3}{*}{ Includind } & $\mathbf{1 - 6}$ & 803 & 59 & $29.6(23.4-36.5)$ \\
\cline { 2 - 5 } & $\mathbf{7 - 1 3}$ & 725 & 339 & $42.2(38.8-45.7)$ \\
\cline { 2 - 5 } & $\mathbf{1 4 - 1 7}$ & 1,761 & 279 & $38.5(34.9-42.1)$ \\
\hline $\mathbf{1 8 - 2 9}$ & 1,862 & 490 & $27.8(21.7-30.0)^{\star}$ \\
\hline $\mathbf{3 0 - 3 9}$ & 1,900 & 546 & $29.4(25.6-31.4)^{\star}$ \\
\hline $\mathbf{4 0 - 4 9}$ & 1,958 & 699 & $36.8(34.4-39.0)$ \\
\hline $\mathbf{5 0 - 5 9}$ & 1,911 & 922 & $47.1(44.6-51.3)^{\star}$ \\
\hline $\mathbf{6 0 - 6 9}$ & 1,807 & 853 & $44.6(41.7-46.9)^{\star}$ \\
\hline $\mathbf{7 0 +}$ & $\mathbf{1 2 , 9 2 6}$ & $\mathbf{7 7 8}$ & $43.1(38.4-45.4)^{\star}$ \\
\hline Overall & $\mathbf{4 , 9 6 5}$ & $\mathbf{3 8 . 4}(\mathbf{3 7 . 6}-\mathbf{4 5 . 4 )}$ \\
\hline
\end{tabular}

Note. * - statistically significant differences with the final value of seroprevalence in the cohort, upward or downward. In all comparison pairs, the level of statistical significance by the z-test was $p<0.001$.

60-69; and 70+ years old (Table 3). Differences from the overall cohort mean were statistically significant at $\mathrm{p}<0.001$. The lowest seroprevalence indicators were found in the groups 18-29 and 30-39 years old. Differences from the cohort mean were statistically significant at $\mathrm{p}<0.001$. Unlike most regions of Russia [6], in Belarus, there was no predominant seroprevalence among children. There was a slightly higher level of seropositivity among children aged 7-13 years. However, the differences were statistically insignificant in comparison with the overall data $(0.05>\mathrm{p}<0.1)$. At the same time, a statistically significant increase in the proportion of seropositive volunteers in older groups may indicate a greater infection in this category of people with coronavi- rus against the background of a limited set of nonpharmacological interventions in the context of an increase in COVID-19 incidence [39]. For a more accurate assessment of the age structure of seropositivity, the distribution of volunteers by level of $\mathrm{Ab}$ to SARS-CoV-2 Nc was determined (Table 4, Fig. 2).

The proportion of volunteers with an $\mathrm{Ab}$ level of $100-186 \mathrm{U} / \mathrm{ml}$ was $12.2 \%$ (95\% CI 10.7-13.8) among children 1-17 years old and decreased to $6.2 \%$ (95\% CI 5.1-7.4) among people aged 70+ years. The differences were statistically significant at $\mathrm{p}<0.0001$. The age dependence had a negative trend and was described by the regression equation $y=0.0712 x^{4}-1.2894 x^{3}+7.9167 x^{2}-19.373 x+25$, with a coefficient of determination of $\mathrm{R}^{2}=0.90$. The ma-

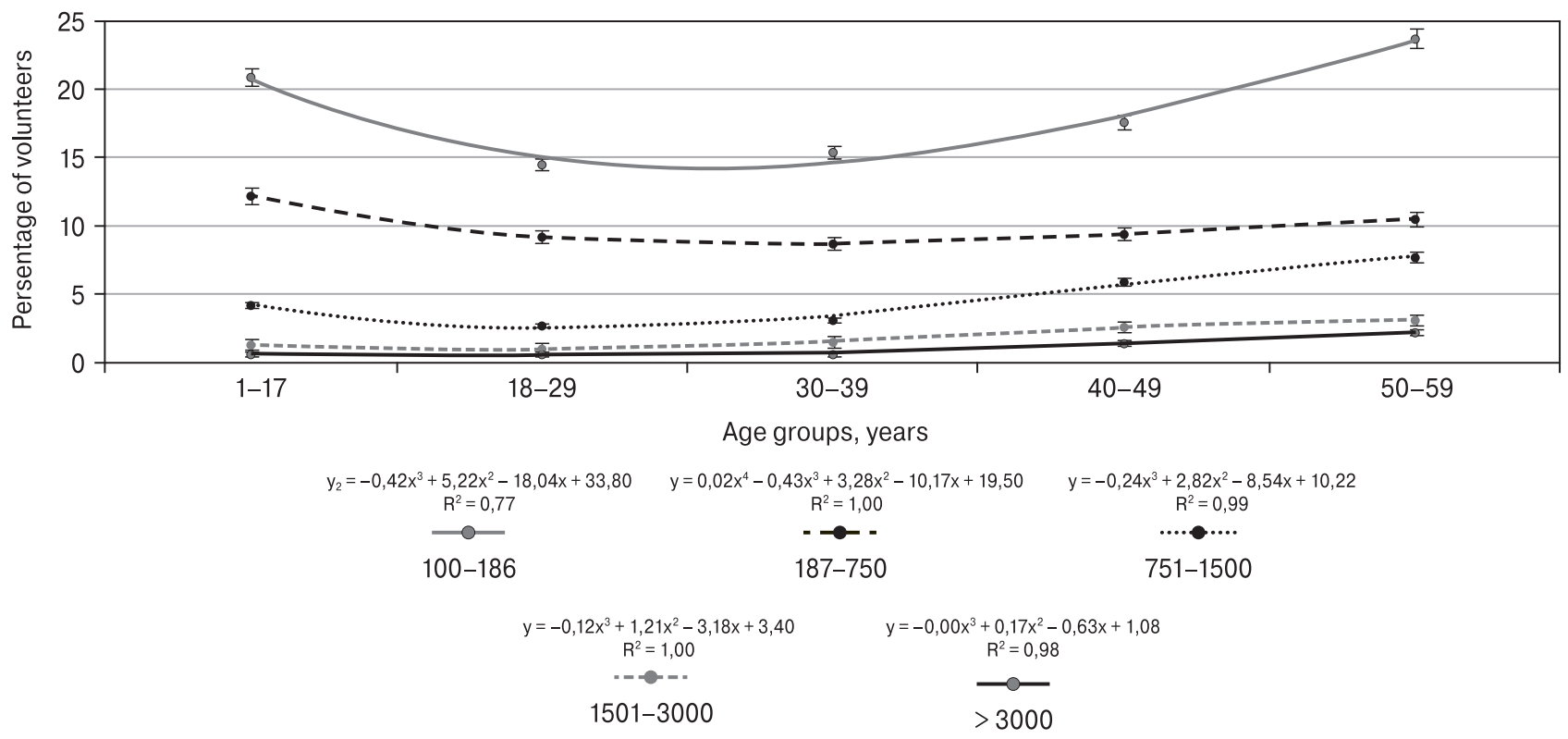

Figure 2. Distribution of the shares of volunteers in different age groups by antibodies to Nc antigens level

Legend: Ab sero-interval groups; colored dots with black vertical lines (confidence intervals) - the proportion of seropositive volunteers who have Abs to SARS-CoV-2 Nc in their blood in the corresponding interval; solid colored lines - forecast trends related to the corresponding sero-interval group. In the upper part of the diagram, the regression equations and $\mathrm{R}^{2}$ determination coefficients are presented (in colors matching those of the corresponding sero-interval group). The numerical values of the points are given in Table 4. 
jority of seropositive volunteers had low $\mathrm{Ab}$ levels in the range 187-750 U/ml. Among individuals in this group, there were: elevations in children $1-17$ years old $(20.9 \%(95 \%$ CI 19.0-22.8) $\mathrm{p}<0.05)$ and those 50-59 years old $(23.7 \%$ (95\% CI 20.1-25.6) p < 0.0001); and decreased $\mathrm{Ab}$ levels in the age groups of 18-19 years old (14.5\% (96\% CI 12.8-16.2) $\mathrm{p}<0.0001)$ and 30-39 years old (15.4\% (95\% CI 13.8-17.1) p $<0.0001)$.

An attempt to build a linear trend turned out to be unsatisfactory, since $\mathrm{R}^{2}$ was -0.11 . Use of a 5 th order polynomial was more successful $\left(\mathrm{y}=0.0808 \mathrm{x}^{5}-\right.$ $\left.1.517 x^{4}+9.9769 x^{3}-26.621 x^{2}+24.404 x+14.5\right)$, with $\mathrm{R} 2$ of 0.91 . Interestingly, in this group, the regression also had a negative direction, although not as pronounced as in the first group (Fig. 2). Two processes described were observed in individuals with very low or low Abs to SARS-CoV-2 Nc.

A change in trend was noted in volunteers with average $\mathrm{Ab}$ values ranging from 750 to $1500 \mathrm{U} / \mathrm{ml}$. When approximated by the least squares method, the slope coefficient $(\operatorname{tg} \alpha)$ was: -0.8 in the Ab sero-interval group 100-186 U/ml; and $\operatorname{tg} \alpha$ was 0.5 in the $\mathrm{Ab}$ sero-interval group $186-150 \mathrm{U} / \mathrm{ml}$. This indicates that the lowest $\mathrm{Ab}$ levels are inherent in children and individuals aged 18-29 years. As age increases, Ab levels increase. This increase started at the $186-750 \mathrm{U} / \mathrm{ml}$ $\mathrm{Ab}$ level and reached its maximum in the group with Abs in the $751-1500 \mathrm{U} / \mathrm{ml}$ range $(\operatorname{tg} \alpha=1.0)$. In addition, the minimum level was noted among 18-29 year olds (2.7\% [95\% CI 2.0-3.5] p < 0.0001) (Fig. 2, green dots). Consistent with a linear prognosis, Ab levels increased with age (Fig. 2). Among persons 40-49 years old, there were $5.9 \%$ (95\% CI 4.8-7.0). In the group of 60-69 years old, their share increased to $9.6 \%(95 \%$ CI 8.3-11.0) ( $\mathrm{p}<0.0001)$. Finally, among volunteers aged $70+$ years, there was a statistically insignificant decrease (8.3\% [95\% CI 7.0-9.6]).

In the last two groups (Ab levels 1,501-3,000 and $>3000 \mathrm{U} / \mathrm{ml}$ ), a similar tendency was observed even with a decrease in the arithmetic value of the proportion of seropositivity (Table 4). Thus, the interage distribution, of the proportion of seropositive individuals within the same serological interval, showed: a decrease in Ab levels among young and middle-aged people; and a statistically significant increase among older volunteers. This relationship between age and the level of anti-Nc Abs can be considered one of the features of SARS-CoV-2, which has been established in other studies $[47,55]$. One of the probable reasons for this phenomenon may be more severe COVID-19 courses due to the widespread prevalence of premorbid pathology and decreased immune responsiveness in elderly and senile people [4, 34].

\section{Regional seroprevalence structure of the Belarusian population}

The study of population seroprevalence was conducted in all seven administrative regions of the Republic (Table 5).

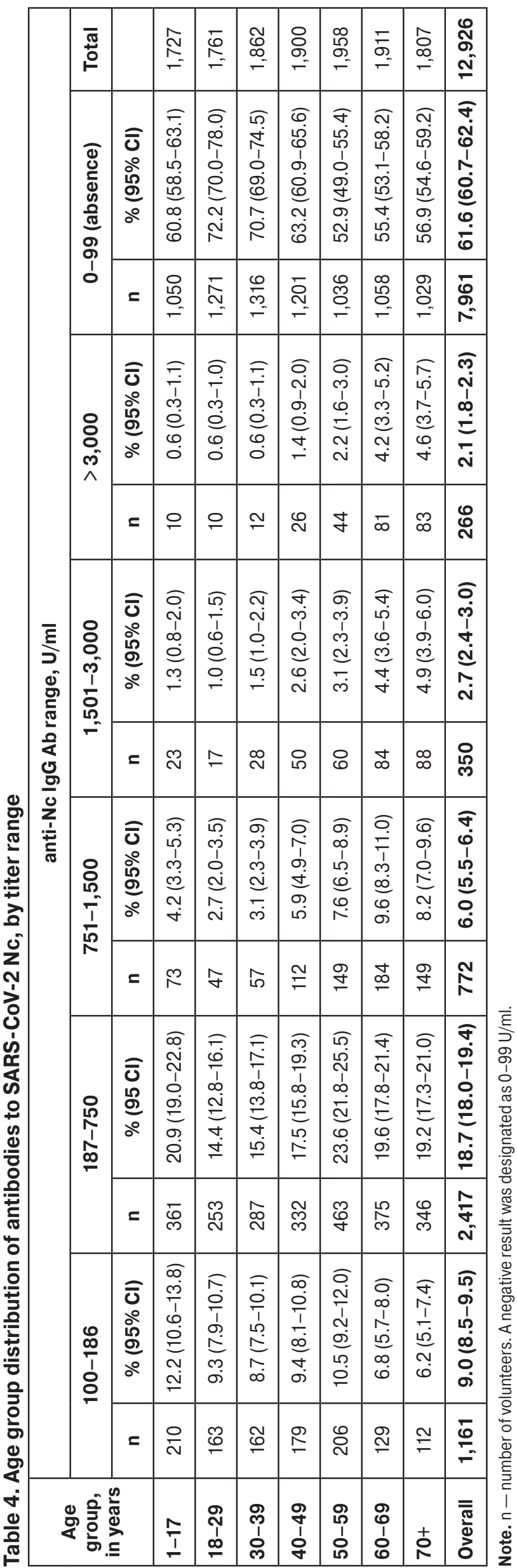


Table 5. Morbidity and SARS-CoV-2 seroprevalence in volunteers living in different regions of Belarus

\begin{tabular}{|l|c|c|c|c|c|}
\hline \multirow{2}{*}{ Location } & \multirow{2}{*}{$\begin{array}{c}\text { Population } \\
\text { density, per km }\end{array}$} & \multicolumn{2}{|c|}{ Studied volunteers } & Seroprevalence, \% & \multirow{2}{*}{ Morbidity, \%ooo } \\
\cline { 3 - 6 } & Total & Seropositive & CI) & \\
\hline Brest Region & 41 & 1,690 & 698 & $41.3(34.4-43.7)$ & 61.0 \\
\hline Vitebsk Region & 28 & 1,648 & 587 & $35.6(33.3-38.0)$ & 86.8 \\
\hline Grodno Region & 40 & 1,685 & 709 & $42.1(35.0-44.5)$ & 61.7 \\
\hline Gomel Region & 34 & 1,606 & 635 & $39.5(37.1-42.0)$ & 48.5 \\
\hline Mogilev Region & 35 & 1,718 & 685 & $39.9(33.7-42.2)$ & 77.8 \\
\hline Minsk Region & 37 & 1,602 & 544 & $34.0(31.6-36.3)^{\star}$ & 93.5 \\
\hline Minsk & 5761 & 2,977 & 1,107 & $37.2(35.5-38.9)$ & 130.4 \\
\hline Overall & $\mathbf{4 5}$ & $\mathbf{1 2 , 9 2 6}$ & $\mathbf{4 , 9 6 5}$ & $\mathbf{3 8 . 4}(\mathbf{3 7 . 6 - 3 9 . 3 )}$ & $\mathbf{8 0 . 9}$ \\
\hline
\end{tabular}

Note. * - statistically significant difference with the overall value.

Among the surveyed Belarusian regions, higher seroprevalence (relative to the average for the Republic) was noted in the Grodno and Brest regions. They were, however, statistically insignificant. The lowest seroprevalence was found among volunteers in the Minsk Region (differences were statistically significant at $\mathrm{p}<0.0001)$. A slightly higher proportion of seropositive volunteers was found in Minsk, while in other regions there was a significant morbidity. At first glance, there is no statistically significant relationship between morbidity and seroprevalence, which somewhat contradicts previously obtained results in other territories [9, 11, 12].

We tried to assess the presence of any relationship between morbidity and population density, assuming that these two indicators may be correlated. Such a dependence does exist with: a correlation coefficient of $\mathrm{r}=0.64(0.05>\mathrm{p}<0.1)$; a descending straight trend line $(\mathrm{y}=-0.292 \ln (\mathrm{x})+1.7687)$; and a determination coefficient of $\mathrm{R}^{2}=0.41$. The connection turned out to be weak $(0.05>\mathrm{p}<0.1)$ (Fig. 3).

Based on these data, it can be concluded that an increase in seroprevalence is accompanied by a de-

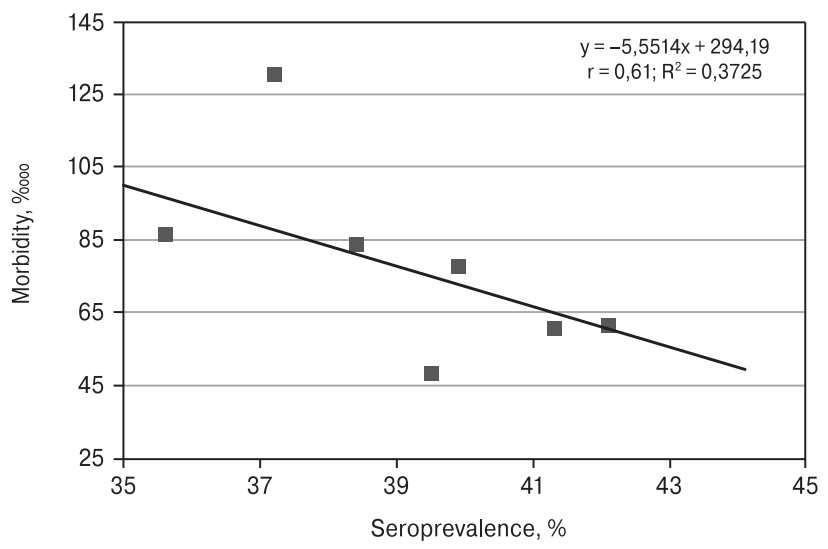

Figure 3. Correlation between morbidity and seroprevalence

Note. On the $x$ and $y$ axes, morbidity and seroprevalence are expressed as $\log _{10}$. The correlation coefficient $(r)$, the determination coefficient $R^{2}$, and the regression equation are shown. crease in the incidence rate per 100,000 population. This conclusion is quite consistent with published ideas that: as the level of herd immunity grows in the population, the rate of spread of the disease decreases until its complete cessation [23, 42, 43]. The relationship between population density and seroprevalence turned out to be slightly more significant. The trend line is an ascending straight line: $y=0.2904 \ln (x)+$ 1.7182; correlation coefficient $0.70(0.05>\mathrm{p}<0.1)$; and a determination coefficient of $\mathrm{R}^{2}=0.47$ (Fig. 4).

In this case, the regression line was ascending. This reflects the well known fact in epidemiology that there is a direct relationship between population density and morbidity. Demographically, Belarus is a territory with a relatively evenly distributed population. As noted earlier, the average population density in the country is 45 per $\mathrm{km}^{2}$. An exception to the trend is the capital of the Republic, Minsk, where the population density is 5819 per $\mathrm{km}^{2}$ (126.5-fold higher than the national average). Interestingly, even with such a density, the seroprevalence level $(37.2 \%$ [95\% CI 35.5-38.9]) does not differ from the national average (38.4\% [95\% CI 37.6-39.3]).

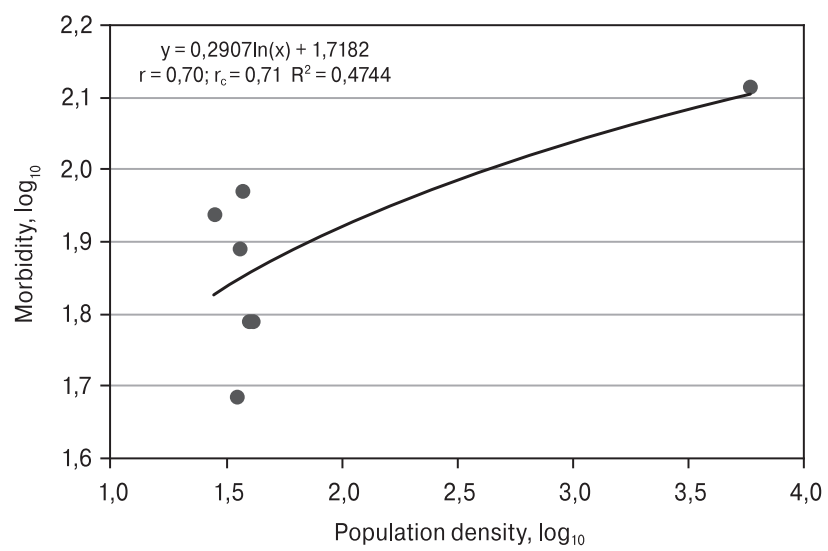

Figure 4. Correlation between morbidity rate and population density

Note. On the $x$ and $y$ axes, incidence and population density are expressed as $\log _{10}$. The correlation coefficient ( $r$ ), determination coefficient $\mathrm{R}^{2}$, and the regression equation are shown. 
Thus, the performed correlation analysis confirmed the presence of a statistically significant relationship between population density and morbidity, as well as between population density and seroprevalence. The latter phenomenon was revealed in other territories as well [13]. The desire to break this connection is precisely what caused the widespread use of self-isolation regimes in Belarus [22, 24, 26]. It can be assumed that the nature of the relationship between population density and morbidity is, to some extent, due to the late introduction of restrictive antiepidemic measures to protect the population from SARS-CoV-2 [39].

\section{The structure of (SARS-CoV-2 Nc) seroprevalence by profession}

A factor such as profession can have a significant impact on the level of seroprevalence. There is an extensive list of professions that involve constant, broad contact with the surrounding population. Visual, and often tactile, contact with those around them are typical for workers in: healthcare; education; trade; transportation; catering; consumer services (hair salons, massage parlors, spas); and a number of other professions, such as manufacturing, were working remotely or in self-isolation isn't feasible $[21,30,39$, 46]. In Belarus, a survey of SARS-CoV-2 Ab seroprevalence was carried out among representatives of 12 professional groups (Table 6).

The distribution of seroprevalence, among 8,241 working-age volunteers in 12 professional groups, was generally quite homogeneous (Table 5). Unlike other researchers, we were unable to identify predominant

Table 6. SARS-CoV-2 seroprevalence among different professions groups

\begin{tabular}{|c|c|c|c|}
\hline Professions & 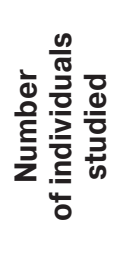 & 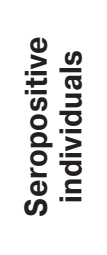 & 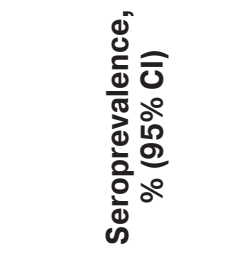 \\
\hline Healthcare & 1,504 & 570 & $37.9(35.4-40.4)$ \\
\hline Science & 91 & 33 & $36.3(26.4-47.0)$ \\
\hline Business & 540 & 173 & $32.0(28.1-36.2)^{\star}$ \\
\hline Education & 1,126 & 440 & $39.1(36.2-42.0)$ \\
\hline The Arts & 148 & 56 & $37.8(30.0-46.2)$ \\
\hline Manufacturing & 1,201 & 457 & $38.1(35.3-40.9)$ \\
\hline Transportation & 328 & 151 & $46.0(40.5-51.6)^{\star}$ \\
\hline Armed Forces & 99 & 39 & $39.4(29.7-49.7)$ \\
\hline Civil Service & 365 & 147 & $40.3(35.2-45.5)$ \\
\hline Office Work & 1,675 & 614 & $36.7(34.3-39.0)$ \\
\hline Unemployed & 340 & 116 & $34.1(29.1-39.4)$ \\
\hline Other & 823 & 275 & $33.4(30.2-36.7)$ \\
\hline Overall & 8,241 & 3,071 & $37.3(36.2-38.3)$ \\
\hline
\end{tabular}

Note. ${ }^{*}$ - statistically significant differences from the mean $(p<0.0001)$. seroprevalence values in healthcare $[8,19]$ or education [14] professional groups. A higher SARS-CoV-2 seroprevalence was found among transport workers: 45.2\% (95\% CI 41.6-52.5; $\mathrm{p}<0.0001$ ). It can be assumed that this group of volunteers was dominated by employees of public transport enterprises who have frequent contact with passengers. The lowest seroprevalence was noted among business professionals: $32.0 \%$ (95\% CI 28.1-36.2; $\mathrm{p}<0.0001$ ). In the remaining groups, statistically significant differences from the group mean were not found (Table 5). Thus, analysis of seroprevalence by professional group did not find substantial differences in Belarus as a whole.

\section{Seroprevalence among COVID-19 convalescents and their contacts}

Among the volunteers who participated in the study, 4,056 people indicated in the questionnaire that they had suffered from COVID-19 (31.4\% [95\% CI 30.6-32.2]). In the entire group of convalescents, the number of seropositive was 2,611 (64.4\% [95\% CI 62.6-65.8]). Correlated with the cumulative number of infections in Belarus as a whole (as of May $19,2021)$, the total number of convalescents in the cohort was $1.07 \%$ (95\% CI 1.03-1.10).

Keeping in mind that each patient in the latent and/ or manifest period is highly likely to be a spreader of infection, it is reasonable to assume that a certain number of people have been in contact with patients [42, 43]. The share of such persons may vary and largely depends on the effectiveness of restrictive administrative measures. During the survey process (questionnaire), 4,967 people (38.4\% [95\% CI 37.6-39.3]) were identified with verified patient and/or convalescent contact. Among them, the number of seropositive persons was $2,043(41.3 \%$ [95\% CI 39.7-42.5]).

Table 7. Age distribution of SARS-CoV-2 seropositive volunteers with an asymptomatic COVID-19 course

\begin{tabular}{|c|c|c|c|}
\hline \multirow[b]{2}{*}{$\begin{array}{l}\text { Age } \\
\text { group, } \\
\text { years }\end{array}$} & \multicolumn{2}{|c|}{$\begin{array}{c}\text { Number } \\
\text { of seropositive } \\
\text { individuals }\end{array}$} & \multirow[b]{2}{*}{$\begin{array}{l}\text { Asymptomatic } \\
\text { seropositive } \\
\text { individuals, } \\
\%(95 \% \mathrm{Cl})\end{array}$} \\
\hline & $\begin{array}{l}\text { त्ञ } \\
\text { ثै }\end{array}$ & 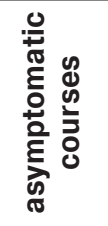 & \\
\hline $1-17$ & 677 & 440 & $65.0(61.3-68.6)^{\star}$ \\
\hline $16-29$ & 490 & 248 & $50.6(46.1-55.1)$ \\
\hline $30-39$ & 546 & 258 & $47.2(43.0-52.0)$ \\
\hline $40-49$ & 699 & 265 & 37.9 (34.3-41.6) \\
\hline $50-59$ & 922 & 349 & $37.8(34.7-41.1)$ \\
\hline $60-69$ & 853 & 308 & $36.1(32.9-39.4)$ \\
\hline $70+$ & 778 & 383 & $49.2(45.7-52.8)$ \\
\hline Overall & 4,964 & 2,251 & $45.3(44.0-46.7)$ \\
\hline
\end{tabular}

Note. * - statistically significant difference from the cohort mean. 


\section{Distribution of asymptomatic COVID-19 forms among seropositive volunteers}

In the surveyed cohort, asymptomatic individuals with a positive PCR test result were not identified. Antibodies to (SARS-CoV-2) Nc were identified in 4,964 people (38.4\% [95\% CI 37.6-39.2]). Of them, 2,251 people (45.3\% [95\% CI 44.0-46.7]) had no symptoms or indications of COVID-19, except for the aforementioned antibodies. This group of individuals was classified as seropositive volunteers with an asymptomatic course of infection (Table 7).

In a number of Russian regions, the share of asymptomatic, seropositive individuals ranged from 90 to $100 \%$ [7]. The share of such persons in Belarus, however, was about 2.2-fold lower (Table 6). The largest number of asymptomatic volunteers was found in the group $1-17$ years old $(p<0.0001)$. Some higher seropositivity values were noted in the groups 16-29 years old and $70+$ years old, but they were statistically insignificant $(\mathrm{p}=0.1)$.

\section{Seroprevalence among vaccinated individuals}

Among the volunteer cohort who participated in the program assessing SARS-CoV-2 seroprevalence in the population, 1,735 people received SARSCoV-2 vaccines. Twenty six volunteer samples were invalid. Therefore, further analysis was carried out of 1709 vaccinated volunteers (1,542 immunized with Sputnik V, 167 immunized with BBIBP-CorV).

The BBIBP-CorV vaccine induces Abs to all antigens of the SARS-CoV-2 complex. In response to Sputnik V vaccination, only Abs against the RBD are produced (not against Nc) [35, 54]. Among Sputnik V-vaccinated volunteers, however, about $20 \%$ were found to have anti-Nc Abs. Presumably, they were formed as a result of a transmitted asymp- tomatic infection. This assumption is in satisfactory agreement with the data on Nc seropositivity in the entire cohort, which amounted to $38.4 \%$ (95\% CI 37.6-45.4) (Table 1). Although the proportion of seropositive individuals is, in general, statistically significantly higher than those vaccinated (Table 8), it includes unvaccinated children and convalescents (who are recommended to observe a 3-6 month delay in vaccination). Considering that the Sputnik V vaccine does not induce anti-Nc Abs by nature of its design, we interpreted their presence in vaccinated volunteers as a sign of post-infectious immunity. Accordingly, anti-RBD Abs were attributed to postvaccination immunity.

BBIBP-CorV vaccine, being polyvalent, naturally induced production of Abs against the entire viral antigen range. The proportion of Nc seropositive following BBIBP-CorV vaccination was 2.8-fold higher than that with Sputnik V. In this regard, it is logical to assume that the real contribution of the Chinesemade vaccine to the proportion of those seropositive for Nc Abs in immunized volunteers may be about $42 \%$. Of course, this is a purely speculative conclusion that requires additional verification. In addition, this $42 \%$ refers to only 167 individuals vaccinated BBIBP-CorV. When recalculated for the entire vaccinated cohort, the additional contribution to the total proportion of individuals with anti-Nc plasma Abs will be only $4.1 \%$ (95\% CI 3.2-5.1). This does not statistically differ from the proportion of individuals in which immunity from both Ab classes is absent.

As for Abs to the RBD, no surprises were noted. Both vaccines created comparable immunity with seroprevalence levels from 94.0\% (95\% CI 89.397.1) to $96.0 \%$ (95\% CI 94.9-96.9); differences between the indicators were not statistically significant (Table 8). Thus, these vaccines used in the Republic

Table 8. Seroprevalence in the surveyed volunteers vaccinated against SARS-CoV-2

\begin{tabular}{|c|c|c|c|c|c|c|c|}
\hline \multirow[t]{2}{*}{ Vaccine } & \multirow[t]{2}{*}{$\begin{array}{c}\text { Total } \\
\text { vaccinated }\end{array}$} & \multicolumn{2}{|c|}{$\begin{array}{l}\text { Post-infectious immunity } \\
\text { is present (anti-Nc IgG } \\
\text { antibodies) }\end{array}$} & \multicolumn{2}{|c|}{$\begin{array}{l}\text { Post-vaccination immunity } \\
\text { is present (anti-RBD IgG } \\
\text { antibodies) }\end{array}$} & \multicolumn{2}{|c|}{ Absence of immunity* } \\
\hline & & $\mathbf{n}$ & $\%(95 \% \mathrm{Cl})$ & $\mathbf{n}$ & $\%(95 \% \mathrm{Cl})$ & $\mathrm{n}$ & $\%(95 \% \mathrm{Cl})$ \\
\hline Sputnik V & 1542 & 357 & $23.2(21.1-25.3)$ & 1,480 & $96.0(94.9-96.9)$ & 56 & $3.6(2.8-4.7)$ \\
\hline BBIBP-CorV & 167 & 109 & $65.3(57.5-72.5)^{\star \star}$ & 157 & $94.0(89.3-97.1)$ & 8 & $4.8(2.1-9.2)$ \\
\hline Overall & 1,709 & 466 & $27.3(25.2-29.5)$ & 1,637 & 95.8 (94.7-96.7) & 64 & $3.7(2.9-4.8)$ \\
\hline
\end{tabular}

Note. * - there is neither post-infectious nor post-vaccination immunity, ${ }^{* *}$ — the presence of anti-Nc Abs in those vaccinated with BBIBP-CorV cannot be unambiguously interpreted as a consequence of prior infection.

Table 9. Presence of IgG antibodies to various SARS-CoV-2 proteins in volunteers vaccinated with Sputnik V (N=1,542)

\begin{tabular}{|l|c|c|c|}
\hline \multicolumn{2}{|c|}{ Sputnik V vaccine } & \multicolumn{2}{c|}{ anti-Nc IgG antibodies } \\
\cline { 2 - 3 } & & present $(\mathbf{n}=\mathbf{3 5 7})$ & absent $\mathbf{( n = 1 , 1 8 5 )}$ \\
\hline \multirow{2}{*}{$\begin{array}{l}\text { IgG antibodies } \\
\text { to the RBD domain } \\
\text { (S protein), number } \\
\text { of volunteers }\end{array}$} & present $(\mathrm{n}=1480)$ & 351 & 1,129 \\
\cline { 2 - 4 } & absent $(\mathrm{n}=62)$ & $22.8 \%(95 \% \mathrm{Cl} 20.7-25.0)$ & $73.2 \%(95 \% \mathrm{Cl} 70.9-75.4)$ \\
\hline
\end{tabular}


Table 10. Presence of IgG antibodies to various SARS-CoV-2 proteins in volunteers vaccinated with BBIBP-CorV $(\mathrm{N}=167)$

\begin{tabular}{|l|c|c|c|}
\hline \multicolumn{2}{|c|}{ BBIBP-CorV vaccine } & \multicolumn{2}{c|}{ anti-Nc IgG antibodies } \\
\cline { 2 - 4 } & & present $(\mathbf{n}=\mathbf{1 0 9})$ & absent $(\mathbf{n}=\mathbf{5 8})$ \\
\hline $\begin{array}{l}\text { IgG antibodies } \\
\text { to the RBD domain } \\
\text { (S protein), number } \\
\text { of volunteers }\end{array}$ & present $(\mathrm{n}=157)$ & 107 & 50 \\
\cline { 2 - 4 } & absent $(\mathrm{n}=10)$ & $64.1 \%(95 \% \mathrm{Cl} 56.3-71.3)$ & $29.9 \%(95 \% \mathrm{Cl} 23.5-37.3)$ \\
\hline
\end{tabular}

of Belarus have shown high efficiency in terms of $\mathrm{Ab}$ production to the RBD of SARS-CoV-2.

Further analysis was carried out only in relation to those immunized with Sputnik V, the composition of which allows: the most complete assessment of the contribution of vaccination to the structure of herd immunity (Table 9); and to compare these data with BBIBP-CorV vaccination results (Table 10). The number of persons with post-vaccination SARSCoV-2 immunity induced by Sputnik V was 1,129.

Similar calculations for the BBIBP-CorV vaccine showed that its contribution to post-vaccination immunity was $0.4 \%$ (95\% CI $0.3-0.5)$. The contribution of the BBIBP-CorV vaccine to $\mathrm{Nc} \mathrm{Ag} \mathrm{immu-}$ nity, calculated according to the principle above, was $0.9 \%$ (95\% CI $0.7-1.9$ ). The total contribution of Abs to the BBIBP-CorV vaccine to SARS-CoV-2 herd immunity was: $0.4+0.9=1.3 \%$.

Taking into account the sum of post vaccination immunity from Sputnik V (1129 people) and the number of seropositive individuals with post infectious immunity (4,965 people), relative to the total cohort $(12,926)$, the final indicator of SARS-CoV-2 herd immunity was $47.1 \%$ (95\% CI 46.3-48.0). This is the average level of seroprevalence in the population of the Republic of Belarus.

\section{Discussion}

Based on the overall results of the study, it can be concluded that the epidemic process, of novel coronavirus infection in Belarus, can be characterized as moderately intense. This is manifested as a high proportion of convalescents, although it is worth noting that a noticeable morbidity did not lead to the activation of transmission or the appearance of a significant number of contact persons. The age structure of seroprevalence, in contrast to a number of Russian regions [10, 11, 13, 41], was characterized by a statistically significant increase in the indicator among persons in older age groups $(50-70+$ years; $\mathrm{p}<0.0001$ ) (Table 3). When quantifying Abs SARSCoV-2 Nc, it was shown that: the minimum Ab levels $(100$ to $750 \mathrm{U} / \mathrm{ml})$ prevailed among volunteers in the age groups $1-17$ and $18-29$ years old; and the maximum levels (751 to $3000+\mathrm{U} / \mathrm{ml}$ ) were identified among persons aged 50 to $70+$ years. This is probably, to a certain extent, associated with a more severe disease course in elderly and senile people $[4,28,44]$.
When analyzing the relationship between seroprevalence and morbidity, an inverse correlation was found (rank correlation coefficient $0.61, \mathrm{p}<0.05$; Fig. 3). Other features were revealed when assessing the influence of occupational factors on seroprevalence. Unlike other territories [27, 33, 38, 48], a predominant seroprevalence among medical workers was not established in Belarus. At the same time, there was a statistically significant increase in the proportion of seropositive people among transport workers.

The analysis of seroprevalence among convalescents and contact persons may be of some interest. First of all, attention is drawn to a rather large share of volunteers who indicated a COVID-19 illness, which amounted to 4,056 people. Of them, 2,611 people were seropositive for Abs SARS-CoV-2 Nc (64.4\% [95\% CI 62.6-65.8]). Naturally, a question arises about the reasons behind the lack of Abs among the remaining $35 \%$. The answer likely lies in the work of $\mathrm{Wu}$ et al. [53], in which it was shown that about $30 \%$ of convalescents produce specific Abs in titers below detection thresholds. However, if physical protection measures are not followed, they are able to spread the virus through exhaled air, coughing, or sneezing $[25,45]$.

In the study, verified contacts with patients or convalescents were found in 4967 people. Of them, 2,043 had Abs to SARS-CoV-2 Nc $(41.3 \%$ [95\% CI 39.7-42.5]). Thus, light protection methods did not prevent SARS-CoV-2 transmission in the susceptible population; transmission was slowed, although probably not as effectively as would be expected according to mathematical models [23].

Among seropositive persons, a significant proportion are so-called asymptomatic cases, in which the disease proceeds without any clinical manifestations, leaving behind only a trace in the form of specific Abs [36]. This is most common among children [31]. There are at least two asymptomatic case types. Firstly, asymptomatic individuals can be defined as those without any signs of COVID-19 other than a positive PCR test. There were no such volunteers in the surveyed cohort. It is believed that such people are able to shed coronavirus longer than symptomatic COVID-19 patients, thus reducing the effectiveness of anti-epidemic measures [36]. The second asymptomatic type includes people without any signs of COVID-19, with the exception of Abs to SARS-CoV-2. Some of them may subsequently 
develop a manifest infection, while others will remain asymptomatic (albeit with low level IgG Abs).

Among seropositive volunteers, the asymptomatic share was $45.3 \%$ (95\% CI 44.0-46.7), which is approximately 2 -fold lower than in Russia and other territories [7, 36]. It can be assumed that this is due to the low level of viral transmission among the population.

The implementation of a COVID-19 vaccination program in the Republic of Belarus started in December, 2020. Two vaccines were used: the Sputnik V vector, heterologous vaccine (Moscow, Russia); and the BBIBP-CorV inactivated vaccine (Sinopharm, PRC). As of May 19, 2021, 3.5\% (95\% CI 3.49-3.51) of the population were vaccinated in Belarus. In other words, no more than 57,000 people a month were vaccinated for six months. At the time of this writing, the proportion of vaccinated persons had increased 4.5-fold and amounted to $15.7 \%$ (95\% CI 15.68-15.72). Among the volunteers, 1709 people were vaccinated (1542 with Sputnik V, 167 with BBIBP-CorV). Both vaccines showed almost equal efficacy in terms of anti-RBD Abs. A significantly higher response to Nc antigen was found in BBIBP-CorV vaccinated individuals. This is expected as the Chinese (polyvalent, inactivated) vaccine naturally induces a larger spectrum of Abs than the Russian Sputnik V (monovalent, vector) vaccine. Despite the small scale of vaccination within the surveyed cohort, it contributed to an increase in the level of herd immunity, on average, up to $47.1 \%$ (95\% CI 46.3-48.0).

The achieved level of immunity is still far from the minimum threshold [42]. The base reproduction number (R0) calculated for Belarus, a value characterizing the rate of spread of infection and the formation of herd immunity [44], was about 1.3. The value of $\mathrm{R}_{0}$ among volunteers, at first glance, is mathematically small. However, one cannot fully rely on it, since it does not take into account: the real prevalence of infection among the population; the effectiveness of non-specific protective measures (distancing, protective masks, self-isolation, etc.); or vaccination.

Taking into account available mathematical modeling methods for COVID-19 morbidity, an $\mathrm{R}_{0}$ of 3.0 to 3.5 is likely more realistic $[17,23]$. This means that the minimum threshold for SARS-CoV-2 immunity cannot be less than 60-65\%. Indeed, an extreme point of view has been expressed by A. Pollard, who believes that herd immunity is generally unattainable [29]. The truth, however, is probably somewhere in between. Even with vaccination of up to $80-90 \%$ of the country, COVID-19, if it does not completely disappear, will likely transform into another seasonal, acute respiratory viral infection. Achieving this limit is only possible with a significant increase in the rate of vaccination of the population.

Thus, at 15 months following the onset of the COVID-19 pandemic, the herd immunity of the Bela- rusian population amounted to $38.4 \%$ (95\% CI 37.645.4). Statistically significant differences between regions of the Republic were not noted, with the exception of a lower proportion of seropositive persons in the Minsk Region ( $\mathrm{p}<0.0001)$.

When assessing the age distribution of Nc seroprevalence (Abs to SARS-CoV-2 Nc), a significantly higher proportion of seropositive persons was noted among the older generation $(50-70+$ years). Further, low levels were found among younger volunteers (139 years old).

There was a statistically significant inverse relationship between morbidity and seroprevalence $(\mathrm{r}=0.61 ; \mathrm{p}<0.05)$. The highest seroprevalence was observed in transportation workers (47.0\% [95\% CI 41.6-52.5]), and the lowest was noted in business $(32.0 \%$ [95\% CI 28.1-36.2]). The relatively high number of convalescents, 4,056 (31.4\% [95\% CI 30.6-32.2]), did not lead to a significant increase in the number of contact persons, amounting to 4,967 people (38.4\% [95\% CI 37.6-39.3]). A characteristic feature of Belarus is the low level of viral transmission from convalescents to healthy individuals. The base reproduction number $\left(\mathrm{R}_{0}\right)$ was 1.3 , which is less than in most other countries and territories.

The Republic is characterized by a low proportion of asymptomatic forms of infection among seropositive volunteers (45.3\% [95\% CI 44.0-46.7]), with a statistically significant predominance of such forms among children $1-17$ years old $(65.0 \%$ [95\% CI 61.368.6]). The obtained results show that the chosen tactics of combating the novel coronavirus have affected the epidemic process in certain ways, but have not led to the formation of an optimal level of herd immunity. The SARS-CoV-2 vaccination deployed in Belarus has contributed to the formation of a high level of anti-RBD immunity. However, the rate of vaccination clearly has not led to a rapid growth in herd immunity so far, which poses a threat of further COVID-19 epidemic growth.

\section{Acknowledgments}

The authors are grateful to the staff of the St. Petersburg Pasteur Institute for their help in studying the biological material for this article: M.S. Voshchev, E.S. Glazkov, A.R. Danilchenko, and also E.S. Ramsay for valuable help (translation, editing) in preparing the text of the article.

\section{Funding}

The work was financed from the state budgets of Belarus and Russia.

\section{Conflict of interests}

The authors declare that they have no conflicts of interest. 


\section{References}

1. В Беларуси зарегистрирован завозной случай коронавируса. Министерство здравоохранения Республики Беларусь. [An imported case of coronavirus has been registered in Belarus. Ministry of Health of the Republic of Belarus (In Russ.)] URL: http://minzdrav.gov.by/ru/sobytiya/v-belarusi-zaregistrirovan-zavoznoy-sluchay-koronavirusa (10.08.2021)

2. Калькулятор значимых различий (z-test). Исследовательская компания RADAR. [Significant Difference Calculator (z-test). RADAR research company. (In Russ.)] URL: https://radar-research.ru/software/z-test_calculator (07.10.2021)

3. Коронавирус-монитор: интерактивная карта распространения и статистика COVID-19. [Coronavirus monitor: interactive map of distribution and statistics of COVID-19 (In Russ.)] URL: https://coronavirus-monitor.info (10.08.2021)

4. Кузник Б.И., Хавинсон В.Х., Смирнов В.С. Особенности патогенеза и течения COVID-19 у лиц пожилого и старческого возраста // Успехи геронтологии. 2020. Т. 33, № 6. С. 1032-1042. [Kuznik B.I., Khavinson V.K., Smirnov V.S. Features of pathogenesis and COVID-19 course for the elderly and old age. Uspekhi gerontologii = Advances in Gerontology, 2020, vol. 33, no. 6, pp. 1032-1042. (In Russ.)] doi: 10.34922/AE.2020.33.6.003

5. Население Беларуси. Countrymeters. [Population of Belarus. Countrymeters (In Russ.)] URL: https://countrymeters.info/ru/ Belarus (10.08.2021)

6. Попова А.Ю., Андреева Е.Е., Бабура Е.А., Балахонов С.В., Башкетова Н.С., Бугоркова С.А., Буланов М.В., Валеуллина Н.Н., Горяев Д.В., Детковская Н.Н., Ежлова Е.Б., Зайцева Н.Н., Историк О.А., Ковальчук И.В., Козловских Д.Н., Комбарова С.Ю., Курганова О.П., Ломовцев А.Э., Лукичева Л.А., Лялина Л.В., Мельникова А.А., Микаилова О.М., Носков А.К., Носкова Л.Н., Оглезнева Е.Е., Осмоловская Т.П., Патяшина М.А., Пеньковская Н.А., Самойлова Л.В., Смирнов В.С., Степанова Т.Ф., Троценко О.Е., Тотолян А.А. Особенности серопревалентности к нуклеокапсиду SARS-CoV-2 у детей в период эпидемии COVID-19 2020 года // Педиатрия. 2021. T. 100, № 3. C. 97-106. [Popova A.Yu., Andreeva E.E., Babura E.A., Balakhonov S.V., Bashketova N.S., Bugorkova S.A., Bulanov M.V., Valeullina N.N., Goryaev D.V., Detkovskaya N.N., Ezhlova E.B., Zaitseva N.N., Istorik O.A., Koval'chuk I.V., Kozlovskikh D.N., Kombarova S.Yu., Kurganova O.P., Lomovtsev A.E., Lukicheva L.A., Lyalina L.V., Mel'nikova A.A., Mikailova O.M., Noskov A.K., Noskova L.N., Oglezneva E.E., Osmolovskaya T.P., Patyashina M.A., Pen'kovskaya N.A., Samoilova L.V., Smirnov V.S., Stepanova T.F., Trotsenko O.E., Totolian A.A. Peculiarities of SARS-CoV-2 nucleocapsid in children during the COVID-19 epidemic of 2020. Pediatriya $=$ Pediatrics, 2021, vol. 100, no. 3, pp. 97-106. (In Russ.)] doi: 10.24110/0031-403X-2021-100-3-97-106

7. Попова А.Ю., Андреева Е.Е., Бабура Е.А., Балахонов С.В., Башкетова Н.С., Буланов М.В., Валеуллина Н.Н., Горяев Д.В., Детковская Н.Н., Ежлова Е.Б., Зайцева Н.Н., Историк О.А., Ковальчук И.В., Козловских Д.Н., Комбарова С.Ю., Курганова О.П., Кутырев В.В., Ломовцев А.Э., Лукичева Л.А., Лялина Л.В., Мельникова А.А., Микаилова О.М., Носков А.К., Носкова Л.Н., Оглезнева Е.Е., Осмоловская Т.П., Патяшина М.А., Пеньковская Н.А., Самойлова Л.В., Смирнов В.С., Степанова Т.Ф., Троценко О.Е., Тотолян А.А. Особенности формирования серопревалентности населения Российской Федерации к нуклеокапсиду SARS-CoV-2 в первую волну эпидемии COVID-19 // Инфекция и иммунитет. 2021. Т. 11, № 2. С. 297-323. [Popova A.Yu., Andreeva E.E., Babura E.A., Balakhonov S.V., Bashketova N.S., Bulanov M.V., Valeullina N.N., Goryaev D.V., Detkovskaya N.N., Ezhlova E.B., Zaitseva N.N., Istorik O.A., Kovalchuk I.V., Kozlovskikh D.N., Kombarova S.Yu., Kurganova O.P., Kutyrev V.V., Lomovtsev A.E., Lukicheva L.A., Lyalina L.V., Melnikova A.A., Mikailova O.M., Noskov A.K., Noskova L.N., Oglezneva E.E., Osmolovskaya T.P., Patyashina M.A., Penkovskaya N.A., Samoilova L.V., Smirnov V.S., Stepanova T.F., Trotsenko O.E., Totolian A.A. Features of developing SARSCoV-2 nucleocapsid protein population-based seroprevalence during the first wave of the COVID-19 epidemic in the Russian Federation. Infektsiya i immunitet $=$ Russian Journal of Infection and Immunity, 2021, vol. 11, no. 2, pp. 297-323. (In Russ.)] doi: 10.15789/2220-7619-FOD-1684

8. Попова А.Ю., Ежлова Е.Б., Мельникова А.А., Андреева Е.Е., Комбарова С.Ю., Лялина Л.В., Смирнов В.С., Алешкин А.В., Кобзева Ю.В., Игнатова Е.Н., Осадчая М.Н., Назаренко Е.В., Антипова Л.Н., Басов А.А., Затевалов А.М., Новикова Л.И., Бочкарева С.С., Лиханская Е.Т., Ломоносова В.И., Тотолян А.А. Коллективный иммунитет к SARSCoV-2 жителей Москвы в эпидемический период COVID-19 // Инфекционные болезни. 2020. T. 18, № 1. C. 8-16. [Popova A.Yu., Ezhlova E.B., Melnikova A.A., Andreeva E.E., Kombarova S.Yu., Lyalina L.V., Smirnov V.S., Aleshkin A.V., Kobzeva Yu.V., Ignatova E.N., Osadchaia M.N., Nazarenko E.V., Antipova L.N., Basov A.A., Zatevalov A.M., Novikova L.I., Bochkareva S.S., Likhanskaia E.T., Lomonosova V.I., Totolian A.A. SARS-CoV-2 herd immunity in Moscow citizens during COVID-19 epidemic period. Infektsionnye bolezni = Infectious Diseases, 2021, vol. 18, no. 1, pp. 8-16.(In Russ.)] doi: 10.20953/17299225-2020-4-8-16

9. Попова А.Ю., Ежлова Е.Б., Мельникова А.А., Балахонов С.В., Чеснокова М.В., Дубровина В.И., Лялина Л.В., Смирнов В.С., Трухина А.Г., Пережогин А.Н., Пятидесятникова А.Б., Брюхова Д.Д., Киселева Н.О., Гефан Н.Г., Гаврилова О.В., Гаврилова Т.А., Ломоносова В.И., Тотолян А.А. Опыт исследования серопревалентности к вирусу SARSCoV-2 населения Иркутской области в период вспышки COVID-19 // Проблемы особо опасных инфекций. 2020. № 3. C. 106-113. [Popova A.Yu., Ezhlova E.B., Mel'nikova A.A., Balakhonov S.V., Chesnokova M.V., Dubrovina V.I., Lyalina L.V., Smirnov V.S., Trukhina A.G., Perezhogin A.N., Pyatidesyatnikova A.B., Bryukhova D.D., Kiseleva N.O., Gefan N.G., Gavrilova O.V., Gavrilova T.A., Lomonosova V.I., Totolian A.A. Experience in studying seroprevalence to SARS-CoV-2 virus in the population of the Irkutsk Region during COVID-19 outbreak. Problemy osobo opasnykh infektsiy = Problems of Particularly Dangerous Infections, 2020, no. 3, pp. 106-113. (In Russ.)] doi: 10.21055/0370-1069-2020-3-106-113

10. Попова А.Ю., Ежлова Е.Б., Мельникова А.А., Башкетова Н.С., Фридман Р.К., Лялина Л.В., Смирнов В.С., Чхинджерия И.Г., Гречанинова Т.А., Агапов К.А., Арсентьева Н.А., Баженова Н.А., Бацунов О.К., Данилова Е.М., Зуева Е.В., Комкова Д.В., Кузнецова Р.Н., Любимова Н.Е., Маркова А.Н., Хамитова И.В., Ломоносова В.И., Ветров В.В., Миличкина A.M., Дедков В.Г., Тотолян А.А. Популяционный иммунитет к SARS-CoV-2 среди населения Санкт-Петербурга в период эпидемии COVID-19 // Проблемы особо опасных инфекций. 2020. T. 3. C. 124-130. [Popova A.Yu., Ezhlova E.B., Mel'nikova A.A., Bashketova N.S., Fridman R.K., Lyalina L.V., Smirnov V.S., Chkhindzheriya I.G., Grechaninova T.A., 
Agapov K.A., Arsent'eva N.A., Bazhenova N.A., Batsunov O.K., Danilova E.M., Zueva E.V., Komkova D.V., Kuznetsova R.N., Lyubimova N.E., Markova A.N., Khamitova I.V., Lomonosova V.I., Vetrov V.V., Milichkina A.M., Dedkov V.G., Totolian A.A. Herd immunity to SARS-CoV-2 among the population in Saint-Petersburg during the COVID-19 epidemic. Problemy osobo opasnykh infektsii $=$ Problems of Particularly Dangerous Infections, 2020, vol. 3, pp. 124-130. (In Russ.)] doi: 10.21055/0370-10692020-3-124-130

11. Попова А.Ю., Ежлова Е.Б., Мельникова А.А., Историк О.А., Мосевич О.С., Лялина Л.В., Смирнов В.С., Черный М.А., Балабышева Н.С., Логинова И.С., Владимирова О.С., Самоглядова И.С., Васев Н.А., Румянцева С.В., Чупалова Е.Ю., Селиванова Г.В., Муравьева М.В., Тимофеева Л.В., Ханкишиева Э.Н., Тыльчевская В.Д., Никитенко Н.Д., Костеницкая Т.И., Виркунен Н.В., Климкина И.М., Кузьмина Т.М., Дегтяренко Н.В., Базунова А.И., Филиппова Л.А., Пальчикова Н.А., Кукшкин А.В., Арсентьева Н.А., Бацунов О.К., Богумильчик Е.А., Воскресенская Е.А., Дробышевская В.Г., Зуева Е.В., Кокорина Г.И., Курова Н.Н., Любимова Н.Е., Ферман Р.С., Хамдулаева Г.Н., Хамитова И.В., Хорькова Е.В., Миличкина А.М., Дедков В.Г., Тотолян А.А. Оценка популяционого иммунитета к SARS-CoV-2 cреди населения Ленинградской области в период эпидемии COVID-19 // Проблемы особо опасных инфекций. 2020. № 3. C. 114-123. [Popova A.Yu., Ezhlova E.B., Mel'nikova A.A., Istorik O.A., Mosevich O.S., Lyalina L.V., Smirnov V.S., Cherny M.A., Balabysheva N.S., Loginova I.S., Vladimirova O.S., Samoglyadova I.S., Vasev N.A., Rumyantseva S.V., Chupalova E.Yu., Selivanova G.V., Muraviova M.V., Timofeeva L.V., Khankishieva E.N., Tylchevskaya V.D., Nikitenko N.D., Kostenitskaya T.I., Virkunen N.V., Klimkina I.M., Kuzmina T.M., Degtyarenko N.V., Bazunova A.I., Filippova L.A., Palchikova N.A., Kukshkin A.V., Arsentieva N.A., Batsunov O.K., Bogumilchik E.A., Voskresenskaya E.A., Drobyshevskaya V.G., Zueva E.V., Kokorina G.I., Kurova N.N., Lyubimova N.E., Ferman R.S., Khamdulaeva G.N., Khamitova I.V., Khorkova E.V., Milichkina A.M., Dedkov V.G., Totolian A.A. Assessment of the herd immunity to SARS-CoV-2 among the population of the Leningrad Region during the during COVID-19 epidemic. Problemy osobo opasnykh infektsiy $=$ Problems of Particularly Dangerous Infections, 2020, no. 3, pp. 114-123. (In Russ.)] doi: 10.21055/0370-1069-2020-3-114-123

12. Попова А.Ю., Ежлова Е.Б., Мельникова А.А., Микаилова О.М., Комбарова С.Ю., Костина М.А., Алешкин А.В., Лялина Л.В., Смирнов В.С., Гвазава К.Р., Козлов А.В., Чапов Е.В., Сычев Д.А., Хаттатова Н.В., Басов А.А., Затевалов А.М., Новикова Л.И., Бочкарева С.С., Лиханская Е.И., Шарова А.А., Ломоносова В.И., Тотолян А.А. Структура серопревалентности к вирусу SARS-CoV-2 среди жителей Московской области в период эпидемической заболеваемости COVID-19 // Инфекционные болезни. 2020. T. 18, № 4. C. 17-26. [Popova A.Yu., Ezhlova E.B., Mel'nikova A.A., Mikailova O.M., Kombarova S.Yu., Kostina M.A., Aleshkin A.V., Lyalina L.V., Smirnov V.S., Gvazava K.R., Kozlov A.V., Chapov E.V., Sychev D.A., Khattatova N.V., Basov A.A., Zatevalov A.M., Novikova L.I., Bochkareva S.S., Likhanskaya E.I., Sharova A.A., Lomonosova V.I., Totolian A.A. Characteristics of SARS-CoV-2 virus seroprevalence in population of Moscow Region during COVID-19 epidemic. Infektsionnye bolezni = Infectious Diseases, 2020, vol. 18, no. 4, pp. 17-26. (In Russ.)] doi: 10.20953/1729-9225-2020-4-17-26

13. Попова А.Ю., Ежлова Е.Б., Мельникова А.А., Смирнов В.С., Лялина Л.В., Козловских Д.Н., Лучинина С.В., Романов С.В., Валеуллина Н.Н., Диконская О.В., Чиркова Г.Г., Малых О.Л., Пономарева А.В., Чистякова И.В., Килячина А.С., Юровских А.И., Котова А.А., Тотолян А.А. Особенности серопревалентности к SARS-CoV-2 населения Среднего и Южного Урала в ранний период пандемии COVID-19 // Эпидемиология и вакцинопрофилактика. 2021. T. 20, № 3. C. 8-18. [Popova A.Yu., Ezhlova E.B., Mel’nikova A.A., Smirnov V.S., Lyalina L.V., Kozlovskikh D.N., Luchinina S.V., Romanov S.V., Valeullina N.N., Dikonskaya O.V., Chirkova G.G., Malykh O.L., Ponomareva A.V., Chistyakova I.V., Kilyachina A.S., Yurovskikh A.I., Kotova A.A., Totolian A.A. Peculiarities of seroprevalence to SARS-CoV-2 in the population of the Middle and Southern Urals during the early period of the COVID-19 pandemic. Epidemiologiya i vaktsinoprofilaktika $=$ Epidemiology and Vaccine Prevention, 2021, vol. 20, no. 3, pp. 8-18. (In Russ.)] doi: 10.31631/2073-3046-2021-203-8-18

14. Попова А.Ю., Ежлова Е.Б., Мельникова А.А., Троценко О.Е., Зайцева Т.А., Лялина Л.В., Гарбуз Ю.А., Смирнов В.С., Ломоносова В.И., Балахонцева Л.А., Котова В.О., Базыкина Е.А., Бутакова Л.В., Сапега Е.Ю., Алейникова Н.В., Бебенина Л.А., Лосева С.М., Каравянская Т.Н., Тотолян А.А. Уровень серопревалентности к SARS-CoV-2 среди жителей Хабаровского края на фоне эпидемии COVID-19 // Журнал микробиологии, эпидемиологии и иммунобиологии. 2021. Т. 98, № 1. С. 7-17. [Popova A.Yu., Ezhlova E.B., Melnikova A.A., Trotsenko O.E., Zaitseva T.A., Lyalina L.V., Garbuz Yu.A., Smirnov V.S., Lomonosova V.I., Balakhontseva L.A., Kotova V.O., Bazykina E.A., Butakova L.V., Sapega E.Yu., Aleinikova N.V., Bebenina L.A., Loseva S.M., Karavyanskaya T.N., Totolian A.A. The seroprevalence of SARS-CoV-2 among residents of the Khabarovsk Krai during the COVID-19 epidemic. Zhurnal mikrobiologii, epidemiologii i immunobiologii $=$ Journal of Microbiology, Epidemiology and Immunobiology, 2021, vol. 98, no. 1, pp. 7-17. (In Russ.)] doi: 10.36233/0372-9311-92

15. Попова А.Ю., Тотолян А.А. Методология оценки популяционного иммунитета к вирусу SARS-CoV-2 в условиях пандемии COVID-19 // Инфекция и иммунитет. 2021. T. 11, № 4. С. 609-616. [Popova A.Yu., Totolian A.A. Methodology for assessing herd immunity to the SARS-CoV-2 virus in the context of the COVID-19 pandemic. Russian Journal of Infection and Immunity = Infektsiya i immunitet, 2021, vol. 11, no. 4, pp. 609-616. (In Russ.)] doi: 10.15789/2220-7619-MFA-1770

16. Расчет необходимой численности выборки. В кн.: Батракова Л.Г. Теория статистики. [Calculation of the required sample size. In: Batrakova L.G. Statistics theory (In Russ.)] URL: https://bstudy.net/672834/sotsiologiya/raschet_neobhodimoy_chislennosti_vyborki Accessed (07.15.2021)

17. Adamik B., Bawiec M., Bezborodov V., Bock W., Bodych M., Burgard J. P., Götz T., Krueger T., Migalska A., Pabjan B., Ożański T., Rafajłowicz E., Rafajłowicz W., Skubalska-Rafajłowicz E., Ryfczyńska S., Szczurek E., Szymański P. Mitigation and herd immunity strategy for COVID-19 is likely to fail. medRxiv., 2020, preprint no. 20043109. doi: 10.1101/2020.03.25.20043109

18. Agresti A. Coull B.A. Approximate is better than "exact" for interval estimation of binomial proportions. Am. Stat., 1998, vol. 52, no. 2, pp. 119-126. doi: 10.2307/2685469

19. Akinbami L.J., Vuong N., Petersen L.R., Sami S., Patel A., Lukacs S.L., Mackey L., Grohskopf L.A., Shehu A., Atas J. SARSCoV-2 seroprevalence among healthcare, first response, and public safety personnel, Detroit Metropolitan Area, Michigan, USA, May-June 2020. Emerg. Infect. Dis., 2020, vol. 26, no. 12, pp. 2863-2871. doi: 10.3201/eid2612.203764 
20. Åslund A. Responses to the COVID-19 crisis in Russia, Ukraine, and Belarus. Eurasian Geogr. Econ., 2020, pp. 1-14. doi: 10.1080/ 15387216.2020.1778499

21. Baker M.G., Peckham T.K., Seixas N.S. Estimating the burden of United States workers exposed to infection or disease: a key factor in containing risk of COVID-19 infection. PLoS One, 2020, vol. 15, no. 4: e0232452. doi: 10.1371/journal.pone.0232452

22. Baril-Tremblay D., Marlats C., Ménagerb L. Self-isolation. J. Math. Econ., 2021, vol. 93: 102483. doi: 10.1016/j.jmateco.2021.102483

23. Britton T., Ball F., Trapman P. A mathematical model reveals the influence of population heterogeneity on herd immunity to SARS-CoV-2. Science, 2020, vol. 369, no. 6505, pp. 846-849. doi: 10.1126/science.abc6810

24. Chung S.-C., Marlow S., Tobias N., Algona A., Algona I., You S.-L, Khunti K., McKee M., Michie S., Pillay D. Lessons from countries implementing find, test, trace, isolation and support policies in the rapid response of the COVID-19 pandemic: a systematic review. BMJ Open., 2021, vol. 11, no. 7: e047832. doi: 10.1136/bmjopen-2020-047832

25. Escandón K., Rasmussen A.L., Bogoch I.I., Murray E.J., Escandón K., Popescu S.V., Kindrachuk J. COVID-19 false dichotomies and a comprehensive review of the evidence regarding public health, COVID-19 symptomatology, SARS-CoV-2 transmission, mask wearing, and reinfection. BMC Infect. Dis., 2020, vol. 121: 710. doi: 10.1186/s12879-021-06357-4

26. Farooq A., Laato S., Islam A.K.M.N. Impact of online information on self-isolation intention during the COVID-19 pandemic: cross-sectional study. J. Med. Internet Res., 2020, vol. 22, no. 5: 19128. doi: 10.2196/19128

27. Galanis P., Vraka I., Fragkou D., Bilali A., Kaitelidoua D. Seroprevalence of SARS-CoV-2 antibodies and associated factors in healthcare workers: a systematic review and meta-analysis. J. Hosp. Infect., 2021, vol. 108, pp. 120-134. doi: 10.1016/ j.jhin.2020.11.008

28. Garnier-Crussard A., Forestier E., Gilbert T., Krolak-Salmon P. Novel Coronavirus (COVID-19) epidemic: what are the risks for older patients? J. Am. Geriatr. Soc., 2020, vol. 68, no. 5, pp. 939-940. doi: 10.1111/jgs.16407.

29. Grover N. Delta variant renders herd immunity from Covid 'mythical'. The Guardian. 2021. August, 10. URL: https://www.theguardian.com/world/2021/aug/10/delta-variant-renders-herd-immunity-from-covid-mythical (15.08.2021)

30. Harris O.O., Leblanc N., McGee K., Randolph S., Wharton M.J., Relf M. Alarm at the gate-health and social inequalities are comorbid conditions of HIV and COVID-19. J. Assoc. Nurses AIDS Care, 2020, vol. 31, no. 4, pp. 367-375. doi: 10.1097/ JNC.0000000000000190

31. Hippich M., Holthaus L., Assfalg R., Zapardiel-Gonzalo J., Kapfelsperger H., Heigermoser M., Haupt F., Ewald D.A., Welzhofer T.C., Marcus B.A., Heck S., Koelln A., Stock J., Voss F., Secchi M., Piemonti L., de la Rosa K., Protzer U., Boehmer M., Achenbach P., Lampasona V., Bonifacio E., Ziegler A.G. A public health antibody screening indicates a 6-fold higher SARS-CoV-2 exposure rate than reported cases in children. Med. (N Y), 2021, vol. 2, no. 2, pp. 149-163.e4. doi: 10.1016/ j.medj.2020.10.003

32. Ikegame S., Siddiquey M.N.A., Hung C.-T., Haas G., Brambilla L., Oguntuyo K.Y., Kowdle S.S., Vilardo A.E., Edelstein A., Perandones C., Kamil J.P., Lee B. Neutralizing activity of Sputnik V vaccine sera against SARS-CoV-2 variants Version 3. medRxiv, 2021, preprint no. 21254660. doi: 10.1101/2021.03.31.21254660.

33. Korth J., Wilde B., Dolff S., Frisch J., Jahn M., Krawczyk A., Trilling M., Schipper L., Cordes S., Ross B., Lindemann M., Kribben A., Dittmer U., Witzke O., Herrmann A., Anastasiou O.E. SARS-CoV-2 seroprevalence in healthcare workers in germany: a follow-up study. Int. J. Environ. Res. Public Health, 2021, vol. 18, no. 9, p. 4540. doi: 10.3390/ijerph18094540

34. Landi F., Barillaro C., Bellieni A., Brandi V., Carfì A., D’Angelo M., Fusco D., Landi G., Lo Monaco R., Martone A.M., Marzetti E., Pagano F., Pais C., Russo A., Salini S., Tosato M., Tummolo A., Benvenuto F., Bramato G., Catalano L., Ciciarello F., Martis I., Rocchi S., Rota E., Salerno A., Tritto M., Sgadari A., Zuccalà G., Bernabei R. The new challenge of geriatrics: saving frail older people from the SARS-CoV-2 pandemic infection. J. Nutr. Health Aging, 2020, vol. 24, pp. 466-470. doi: 10.1007/ s12603-020-1356-x

35. Logunov D.Y., Dolzhikova I.V., Zubkova O.V., Tukhvatulin A.I., Shcheblyakov D.V., Dzharullaeva A.S., Grousova D.M., Erokhova A.S., Kovyrshina A.V., Botikov A.G., Izhaeva F.M., Popova O., Ozharovskaya T.A., Ismagambetov B., Favorskaya I.A., Zrelkin D.I., Voronina D.V., Shcherbinin D.N., Semikhin A.S., Simakova Y.V., Tokarskaya E.A., Lubenets N.L., Egorova D.A., Shmarov M.M., Nikitenko N.A., Morozova L.F., Smolyarchuk E.A., Kryukov E.V., Babira V.F., Borisevich S.V., Naroditsky B.S., Gintsburg A.L. Safety and immunogenicity of an rAd26 and rAd5 vector-based heterologous prime-boost COVID-19 vaccine in two formulations: two open, non-randomised phase 1/2 studies from Russia. Lancet, 2020, vol. 396, no. 10255, pp. 887-897. doi: 10.1016/S0140-6736(20)31866-3

36. Long Q.-X., Tang X.-J., Shi Q.-L., Li Q., Deng H.-J., Yuan J., Hu J.-L., Xu W., Zhang Y., Lv F.-J., Su K., Zhang F., Gong J., Wu B., Liu X.-M., Li J.-J., Qiu J.-F., Chen J., Huang A.-L. Clinical and immunological assessment of asymptomatic SARSCoV-2 infections. Nat. Med., 2020, vol. 26, pp. 1200-1204. doi: 10.1038/s41591-020-0965-6

37. Ma M.L., Shi D.W., Li Y., Hong W., Lai D.Y., Xue J.B., Jiang H.W., Zhang H.N., Qi H., Meng Q.F., Guo S.J., Xia D.J., Hu J.J., Liu S., Li H.Y., Zhou J., Wang W., Yang X., Fan X.L., Lei Q., Chen W.J., Li C.S., Yang X.M., Xu S.H., Wei H.P., Tao S.C. Systematic profiling of SARS-CoV-2-specific IgG responses elicited by an inactivated virus vaccine identifies peptides and proteins for predicting vaccination efficacy. Cell Discov., 2021, vol. 7, no. 1: 67. doi: 10.1038/s41421-021-00309-7

38. Napolitano F., Di Giuseppe G., Montemurro M.V., Molinari A.M., Donnarumma G., Arnese A., Pavia M., Angelillo I.F. Seroprevalence of SARS-CoV-2 antibodies in adults and healthcare workers in Southern Italy. Int. J. Environ. Res. Public Health., 2021, vol. 18, no. 9: 4761. doi: 10.3390/ijerph18094761

39. Nemira A., Adeniyi A.E., Gasich E.L., Bulda K.Y., Valentovich L.N., Krasko A.G., Glebova O., Kirpich A., Skums P. SARSCoV-2 transmission dynamics in Belarus revealed by genomic and incidence data analysis. medRxiv, 2021, preprint no. 21255404. doi: 10.1101/2021.04.13.21255404

40. Nguyen L.H., Drew D.A., Graham M.S., Joshi A.D., Guo C.-G., Ma W., Mehta R.S., Warner E.T., Sikavi D.R., Lo C.-H., Kwon S., Song M., Mucci L.A., Stampfer M.J., Willett W.C., Eliassen A.H., Hart J.E., Chavarro J.E., Rich-Edwards J.W., Davies R., Capdevila J., Lee K.A., Lochlainn M.N., Varsavsky T., Sudre C.H., Cardoso M.J., Wolf J., Spector T.D., Ourselin S., Steves C.J., Chan A.T., on behalf of the Coronavirus Pandemic Epidemiology Consortium. Risk of COVID-19 among front-line 
health-care workers and the general community: a prospective cohort study. Lancet Public Health, 2020, vol. 5, no. 9, pp. e475e483. doi: 10.1016/S2468-2667(20)30164-X

41. Popova A.Y., Smirnov V.S., Andreeva E.E., Babura E.A., Balakhonov S.V., Bashketova N.S., Bugorkova S.A., Bulanov M.V., Valeullina N.N., Vetrov V.V., Goryaev D.V., Detkovskaya T.N., Ezhlova E.B., Zaitseva N.N., Istorik O.A., Kovalchuk I.V., Kozlovskikh D.N., Kombarova S.Y., Kurganova O.P., Lomovtsev A.E., Lukicheva L.A., Lyalina L.V., Melnikova A.A., Mikailova O.M., Noskov A.K., Noskova L.N., Oglezneva E.E., Osmolovskaya T.P., Patyashina M.A., Penkovskaya N.A., Samoilova L.V., Stepanova T.F., Trotsenko O.E., Totolian A.A. SARS-CoV-2 seroprevalence structure of the russian population during the COVID-19 pandemic. Viruses, 2021, vol. 13, no. 8: 1648. doi: 10.3390/v13081648

42. Randolph H.E., Barreiro L. B Herd immunity: understanding COVID-19. Immunity, 2020, vol. 52, no. 5, pp. 737-741. doi: 10.1016/ j.immuni.2020.04.012

43. Rostami A., Sepidarkish M., Leeflang M.M.G., Riahi S.M., Shiadeh M.N., Esfandyari S., Mokdad A.H., Hotez P.J., Gasser R.B. SARS-CoV-2 seroprevalence worldwide: a systematic review and meta-analysis. Clin. Microbiol. Infect., 2020, vol. 27, no. 3, pp. 331-340. doi: 10.1016/j.cmi.2020.10.020

44. Saad-Roy C.M., Levin S.A., Metcalf C.J.E., Grenfell B.T. Trajectory of individual immunity and vaccination required for SARSCoV-2 community immunity: a conceptual investigation. J. R. Soc. Interface., 2021, vol. 18, no. 175: 20200683. doi: 10.1098/ rsif.2020.0683

45. Siebach M.K., Piedimonte G., Ley S.H. COVID-19 in childhood: transmission, clinical presentation, complications and risk factors. Pediatr. Pulmonol., 2021, vol. 56, no. 6, pp. 1342-1356. doi: 10.1002/ppul.25344

46. Siff E.J., Aghagoli G., Gallo Marin B., Tobin-Tyler E., Poitevien P. SARS-CoV-2 transmission: a sociological review. Epidemiol. Infect., 2020, vol. 148: e242. doi: 10.1017/S095026882000240X

47. Smith M., Abdesselem H.B., Mullins M., Tan T.-M., Nel A.J.M., Al-Nesf M.A.Y., Bensmail I., Majbour N.K., Vaikath N.N., Naik A., Ouararhni K., Mohamed-Ali V., Al-Maadheed M., Schell D.T., Baros-Steyl S.S., Anuar N.D., Ismail N.H., Morris P.E., Mamat R.N.R., Rosli N.S.M., Anwar A., Ellan K., Zain R.M., Burgers W.A., Maine E.S., El-Agnaf O.M.A., Blackburn J.M. Age, disease severity and ethnicity influence humoral responses in a multi-ethnic COVID-19 cohort. Viruses, 2021, vol. 13, no. 5: 786. doi: 10.3390/v13050786

48. Varona J.F., Madurga R., Peñalver F., Abarca E., Almirall C., Cruz M., Ramos E., Vázquez J.M.C. Seroprevalence of SARSCoV-2 antibodies in over 6000 healthcare workers in Spain. Int. J. Epidemiol., 2021, vol. 50, no. 2, pp. 400-409. doi: 10.1093/ije/ dyaa 277

49. Wald A., Wolfowitz J. Confidence limits for continuous distribution functions. Ann. Math. Stat., 1939, vol. 10, no. 2, pp. $105-118$.

50. Wang H., Zhang Y., Huang B., Deng W., Quan Y., Wang W., Xu W., Zhao Y., Li N., Zhang .J, Liang H., Bao L., Xu Y., Ding L., Zhou W., Gao H., Liu J., Niu P., Zhao L., Zhen W., Fu H., Yu S., Zhang Z., Xu G., Li C., Lou Z., Xu M., Qin C., Wu G., Gao G.F., Tan W., Yang X. Development of an inactivated vaccine candidate, BBIBP-CorV, with potent protection against SARS-CoV-2. Cell, 2020, vol. 182, no. 3, pp. 713-721.e9. doi: 10.1016/j.cell.2020.06.008

51. WHO. COVID-19 Technical mission of experts to the Republic of Belarus: 8-11 April 2020. Executive summary. URL: https://www. euro.who.int/en/countries/belarus/publications/covid-19-technical-mission-of-experts-to-the-republic-of-belarus-811-april-2020.executive-summary (10.08.2021)

52. WHO. Protocol for a population-based age-stratified sero-epidemiological study of COVID-19 infection in humans. Version 2.0. 2020. URL: https://apps.who.int/iris/bitstream/handle/10665/332188/WHO-2019CoV-Seroepidemiology-2020.2-rus.pdf(18.03.2021)

53. Wu F., Wang A., Liu M., Wang Q., Chen J., Xia S., Yun Ling, Zhang Y., Xun J., Lu L., Jiang S., Lu H., Wen Y., Huang J. Neutralizing antibody responses to SARS-CoV-2 in a COVID-19 recovered patient cohort and their implications. medRxiv, 2020, preprint no. 20047365. doi: 10.1101/2020.03.30.20047365

54. Xia S., Zhang Y., Wang Y., Wang H., Yang Y., Gao G.F., Tan W., Wu G., Xu M., Lou Z., Huang W., Xu W., Huang B., Wang H., Wang W., Zhang W., Li N., Xie Z., Ding L., You W., Zhao Y., Yang X., Liu Y., Wang Q., Huang L., Yang Y., Xu G., Luo B., Wang W., Liu P., Guo W., Yang X. Safety and immunogenicity of an inactivated SARS-CoV-2 vaccine, BBIBP-CorV: a randomised, double-blind, placebo-controlled, phase 1/2 trial. Lancet Infect. Dis., 2021, vol. 21, no. 1, pp. 39-51. doi: 10.1016/S14733099(20)30831-8

55. Yang H.S., Costa V., Racine-Brzostek S.E., Acker K.P., Yee J., Chen Z., Karbaschi M., Zuk R., Rand S., Sukhu A., Klasse P.J., Cushing M.M., Chadburn A., Zhao Z. Association of age with SARS-CoV-2 antibody response. JAMA Netw. Open, 2021, vol. 4, no. 3: e214302. doi: 10.1001/jamanetworkopen.2021.4302

56. Zhang X., Sun S., Xiang Y., Wong J., Klose T., Raoult D., Rossmanna M.G. Structure of Sputnik, a virophage, at 3.5-Å resolution. Proc. Natl. Acad. Sci. USA, 2012, vol. 109, no. 45, pp. 18431-18436. doi: 10.1073/pnas. 1211702109 


\section{Авторы:}

Попова А.Ю., д.м.Н., профессор, руководитель Федеральной службы по надзору в сфере защиты прав потребителей и благополучия человека, Москва, Россия;

Тарасенко А.А., зам. министра здравоохранения и главный государственный санитарный врач Республики Беларусь,

Министерство здравоохранения Республики Беларусь, г. Минск, Беларусь;

Смоленский В.Ю., к.м.н., зам. руководителя Федеральной

службы по надзору в сфере защиты прав потребителей

и благополучия человека, Москва, Россия;

Егорова С.А., д.М.Н., зам. директора по инновациям ФБУН НИИ эпидемиологии и микробиологии имени Пастера,

Санкт-Петербург, Россия;

Смирнов В.С., Д.М.н., профессор, ведущий научный сотрудник лаборатории молекулярной иммунологии ФБУН НИИ эпидемиологии и микробиологии имени Пастера,

Санкт-Петербург, Россия;

Дашкевич А.М., зав. отделом эпидемиологии

ГУ Республиканский центр гигиены, эпидемиологии

и общественного здоровья, г. Минск, Беларусь;

Светогор Т.Н., врач-эпидемиолог отделения надзора

за организациями здравоохранения отдела эпидемиологии,

ГУ Республиканский центр гигиены, эпидемиологии

и общественного здоровья, г. Минск, Беларусь;

Глинская И.Н., К.м.н., зам. главного врача по эпидемиологии

ГУ Республиканский центр гигиены, эпидемиологии и общественного здоровья, г. Минск, Беларусь;

Скуранович А.Л., главный врач ГУ Республиканский центр гигиены, эпидемиологии и общественного здоровья, г. Минск, Беларусь; Миличкина А.М., к.М.Н., главный врач медицинского центра ФБУН НИИ эпидемиологии и микробиологии имени Пастера, Санкт-Петербург, Россия;

Дронина А.М., зам. директора по научной работе

Республиканского научно-практического центра эпидемиологии и микробиологии, г. Минск, Беларусь;

Самойлович Э.0., д.м.н., профессор, зав. лабораторией вакциноуправляемых инфекций ГУ Республиканский научнопрактический центр эпидемиологии и микробиологии,

г. Минск, Беларусь;

Хамитова И.В., К.б.н., зав. центральной клиникодиагностической лабораторией ФБУН НИИ эпидемиологии и микробиологии имени Пастера, Санкт-Петербург, Россия;

Семейко Г.В., к.б.н., ведущий научный сотрудник лаборатории вакциноуправляемых инфекци Республиканского научнопрактического центра эпидемиологии и микробиологии, г. Минск, Беларусь;

Амвросьева Т.В., Д.м.н., профессор, зав. лабораторией инфекций с природным резервуаром Республиканского научнопрактического центра эпидемиологии и микробиологии,

г. Минск, Беларусь;

Шмелева Н.П., К.м.Н., зав. лабораторией гриппа и гриппоподобных заболеваний Республиканского научнопрактического центра эпидемиологии и микробиологии, г. Минск, Беларусь;

Рубаник Л.В., к.б.н., зав. лабораторией диагностики сочетанных бактериально-вирусных инфекций Республиканского научнопрактического центра эпидемиологии и микробиологии, г. Минск, Беларусь;

Есманчик О.П., главный врач городской поликлиники № 39, г. Минск, Беларусь;

Карабан И.А., начальник отдела гигиены, эпидемиологии и профилактики Министерства здравоохранения, г. Минск, Беларусь;

Дробышевская В.Г., врач клинической лабораторной диагностики ФБУН НИИ эпидемиологии и микробиологии имени Пастера, Санкт-Петербург, Россия;

Садовникова Г.В., зам. главного врача ГУ Брестский областной центр гигиены, эпидемиологии и общественного здоровья, г. Брест, Беларусь;

Шилович М.В., зав. отделом эпидемиологии ГУ Брестский областной центр гигиены, эпидемиологии и общественного здоровья, г. Брест, Беларусь;

\section{Authors:}

Popova A.Yu., PhD, MD (Medicine), Professor, Head of the Federal Service for Surveillance of Consumer Rights Protection and Human Wellbeing, Moscow, Russian Federation;

Tarasenko A.A., Deputy Minister and Chief State Sanitary Doctor of the Republic of Belarus, Ministry of Health of the Republic of Belarus, Minsk, Belarus;

Smolenskiy V.Yu., PhD (Medicine), Deputy Head of the Federal Service for Surveillance of Consumer Rights Protection and Human Wellbeing, Moscow, Russian Federation;

Egorova S.A., PhD, MD (Medicine), Deputy Director for Innovation, St. Petersburg Pasteur Institute, St. Petersburg, Russian Federation; Smirnov V.S., PhD, MD (Medicine), Professor, Leading Researcher, Laboratory of Molecular Immunology, St. Petersburg Pasteur Institute, St. Petersburg, Russian Federation;

Dashkevich A.M., Head of the Department of Epidemiology, Republican Center for Hygiene, Epidemiology and Public Health, Minsk, Belarus;

Svetogor T.N., Epidemiologist, Supervision of Healthcare Organizations Division, Department of Epidemiology, Republican Center for Hygiene, Epidemiology and Public Health, Minsk, Belarus; Glinskaya I.N., PhD (Medicine), Deputy Head Physician for Epidemiology, Republican Center for Hygiene, Epidemiology and Public Health, Minsk, Belarus;

Skuranovich A.L., Head Physician of the Republican Center for Hygiene, Epidemiology and Public Health, Minsk, Belarus; Milichkina A.M., PhD (Medicine), Head Physician of the Medical Center of St. Petersburg Pasteur Institute, St. Petersburg, Russian Federation;

Dronina A.M., Deputy Director for Academic Affairs, Republican Scientific and Practical Center for Epidemiology and Microbiology, Minsk, Belarus;

Samoilovich E.0., PhD, MD (Medicine), Professor, Head of the Laboratory of Vaccine-Preventable Infections, Republican Scientific and Practical Center for Epidemiology and Microbiology, Minsk, Belarus;

Khamitova I.V., PhD (Biology), Head of the Central Clinical Diagnostic Laboratory, St. Petersburg Pasteur Institute, St. Petersburg, Russian Federation;

Semeiko G.V., PhD (Biology), Leading Researcher, Laboratory of Vaccine Controlled Infections, Republican Scientific and Practical Center for Epidemiology and Microbiology, Minsk, Belarus; Amvrosyeva T.V., PhD, MD (Medicine), Professor, Head of the Laboratory of Infections with a Natural Reservoir, Republican Scientific and Practical Center for Epidemiology and Microbiology, Minsk, Belarus;

Shmeleva N.P., PhD (Medicine), Head of the Influenza and Influenza-Like Diseases Laboratory, Republican Scientific and Practical Center for Epidemiology and Microbiology, Minsk Belarus;

Rubanik L.V., PhD (Biology), Head of the Laboratory for Diagnostics of Combined Bacterial Viral Infections, Republican Scientific and Practical Center for Epidemiology and Microbiology, Minsk, Belarus; Esmanchik O.P., Head Physician of Polyclinic No. 39, Minsk, Belarus;

Karaban I.A., Head of the Hygiene, Epidemiology and Diseases Prevention Department, Ministry of Health, Minsk, Belarus; Drobyshevskaya V.G., Doctor of Clinical Laboratory Diagnostics, Medical Center of St. Petersburg Pasteur Institute, St. Petersburg, Russian Federation;

Sadovnikova G.V., Deputy Head Physician, Brest Regional Center for Hygiene, Epidemiology and Public Health, Brest, Belarus; Shilovich M.V., Head of the Department of Epidemiology, Brest Regional Center for Hygiene, Epidemiology and Public Health, Brest, Belarus;

Podushkina E.A., Head of the Anti-Epidemic Division, Department of Epidemiology, Brest Regional Center for Hygiene, Epidemiology and Public Health, Brest, Belarus:

Kireichuk V.V., Epidemiologist, Immunoprophylaxis Division, Epidemiology Department, Vitebsk Regional Center for Hygiene, Epidemiology and Public Health, Vitebsk, Belarus;

Petrova O.A., Physician of the Central Clinical Diagnostic Laboratory, St. Petersburg Pasteur Institute, St. Petersburg, Russian Federation; 
Подушкина Е.А., зав. противоэпидемическим отделением отдела эпидемиологии ГУ Брестский областной центр гигиены, эпидемиологии и общественного здоровья, г. Брест, Беларусь; Кирейчук В.В., врач-эпидемиолог отделения иммунопрофилактики отдела эпидемиологии ГУ Витебский областной центр гигиены, эпидемиологии и общественного здоровья, г. Витебск, Беларусь;

Петрова О.А., врач центральной клинико-диагностической лаборатории, ФБУН НИИ эпидемиологии и микробиологии имени Пастера, Санкт-Петербург, Россия;

Бондаренко С.В., зав. противоэпидемическим отделением отдела эпидемиологии ГУ Гомельский областной центр гигиены, эпидемиологии и общественного здоровья,

г. Гомель, Беларусь;

Салажкова И.Ф., зав. отделом эпидемиологии Гу Гомельский областной центр гигиены, эпидемиологии и общественного здоровья, г. Гомель, Беларусь;

Ткач Л.М., зав. противоэпидемическим отделением ГУ Гродненский областной центр гигиены, эпидемиологии и общественного здоровья, г. Гродно, Беларусь;

Шепелевич Л.П., зав. отделением особо опасных инфекций с санитарно-карантинным пунктом эпидемиологического отдела гУ Минский городской центр гигиены и эпидемиологии, г. Минск, Беларусь;

Автухова Н.Л., зам. главного врача ГУ Минский областной центр гигиены, эпидемиологии и общественного здоровья, г. Минск, Беларусь;

Иванов В.М., системный администратор ФБУН НИИ эпидемиологии и микробиологии имени Пастера, Санкт-Петербург, Россия;

Бабило А.C., врач-эпидемиолог противоэпидемического отделения эпидемиологического отдела ГУ Минский областной центр гигиены, эпидемиологии и общественного здоровья, г. Минск, Беларусь;

Навышная М.В., врач-эпидемиолог противоэпидемического отделения эпидемиологического отдела ГУ Витебский областной центр гигиены, эпидемиологии и общественного здоровья, г. Витебск, Беларусь;

Беляев Н.Н., старший научный сотрудник отдела новых технологий ФБУН НИИ эпидемиологии и микробиологии имени Пастера, Санкт-Петербург, Россия;

Зуева Е.В., к.б.н., старший научный сотрудник лаборатории молекулярной иммунологии ФБУН НИИ эпидемиологии и микробиологии имени Пастера, Санкт-Петербург, Россия; Волосарь Л.А., врач-эпидемиолог противоэпидемического отделения эпидемиологического отдела ГУ Минский городской центр гигиены и эпидемиологии, г. Минск, Беларусь Вербов В.Н., к.б.н., зав. отделом новых технологий ФБУН НИИ эпидемиологии и микробиологии имени Пастера, Санкт-Петербург, Россия;

Лихачев И.В., младший научный отдела новых технологий ФБУН НИИ эпидемиологии и микробиологии имени Пастера, Санкт-Петербург, Россия;

Загорская Т.О., зав. отделением особо опасных инфекций отдела эпидемиологии ГУ Минский областной центр гигиены, эпидемиологии и общественного здоровья, г. Минск, Беларусь; Морозова Н.Ф., врач-эпидемиолог отделения особо опасных инфекций отдела эпидемиологии УЗ Могилевский областной центр гигиены, эпидемиологии и общественного здоровья, г. Могилев, Беларусь;

Коробова 3.P., лаборант-исследователь лаборатории молекулярной иммунологии ФБУН НИИ эпидемиологии и микробиологии имени Пастера, Санкт-Петербург, Россия; Губанова А.В., врач клинической лабораторной диагностики центральной клинико-диагностической лаборатории ФБУН НИИ эпидемиологии и микробиологии имени Пастера, Санкт-Петербург, Россия;

Тотолян Арег А., д.м.н., профессор, академик РАН, зав. лабораторией молекулярной иммунологии; директор ФБУН НИИ эпидемиологии и микробиологии имени Пастера, Санкт-Петербург, Россия.
Bondarenko S.V., Head of the Anti-Epidemic Division, Epidemiology Department, Gomel Regional Center for Hygiene, Epidemiology and Public Health, Gomel, Belarus;

Salazhkova I.F., Head of the Epidemiology Department, Gomel Regional Center for Hygiene, Epidemiology and Public Health, Gomel, Belarus;

Tkach L.M., Head of Anti-Epidemic Department, Grodno Regional Center for Hygiene, Epidemiology and Public Health, Grodno, Belarus;

Shepelevich L.P., Head of the Division of Especially Dangerous Infections with a Sanitary-Quarantine Point of the Epidemiological Department, Minsk City Center for Hygiene and Epidemiology, Minsk, Belarus:

Avtukhova N.L., Deputy Head Physician, Minsk Regional Center for Hygiene, Epidemiology and Public Health, Minsk, Belarus; Ivanov V.M., System Administrator, St. Petersburg Pasteur Institute, St. Petersburg, Russian Federation;

Babilo A.S., Epidemiologist, Anti-Epidemic Division, Epidemiology Department, Minsk Regional Center for Hygiene, Epidemiology and Public Health, Minsk, Belarus;

Navyshnaya M.V., Epidemiologist, Anti-Epidemic Division, Epidemiology Department, Minsk Regional Center for Hygiene Epidemiology and Public Health, Minsk, Belarus;

Belyaev N.N., Senior Researcher, New Technologies Department, St. Petersburg Pasteur Institute, St. Petersburg, Russian Federation; Zueva E.V., PhD (Biology), Senior Researcher, Laboratory of Molecular Immunology, St. Petersburg Pasteur Institute, St. Petersburg, Russian Federation;

Volosar L.A., Epidemiologist, Anti-Epidemic Division, Epidemiology Department, Minsk City Center for Hygiene and Epidemiology, Minsk, Belarus

Verbov V.N., PhD (Biology), Head of the New Technologies Department, St. Petersburg Pasteur Institute, St. Petersburg, Russian Federation;

Likhachev I.V., Junior Researcher, New Technologies Department, St. Petersburg Pasteur Institute, St. Petersburg, Russian Federation; Zagorskaya T.O., Head of the of the Division of Especially Dangerous Infections, Epidemiology Department, Minsk Regional Center for Hygiene, Epidemiology and Public Health, Minsk, Belarus; Morozova N.F., Epidemiologist, Division of Especially Dangerous Infections, Epidemiology Department, Mogilev Regional Center for Hygiene, Epidemiology and Public Health, Mogilev, Belarus Korobova Z.R., Laboratory Assistant, Laboratory of Molecular Immunology, St. Petersburg Pasteur Institute, St. Petersburg, Russian Federation;

Gubanova A.V., Doctor of Clinical Laboratory Diagnostics, Centra Clinical Diagnostic Laboratory, St. Petersburg Pasteur Institute,

St. Petersburg, Russian Federation

Totolian Areg A., PhD, MD (Medicine), Professor, RAS Full Member, Head of the Laboratory of Molecular Immunology; Director, St. Petersburg Pasteur Institute, St. Petersburg, Russian Federation. 